\title{
Relevant Features of a Triethylene Glycol Dimethyl Ether-Based Electrolyte for Application in Lithium Battery
}

Lorenzo Carbone, ${ }^{\mathrm{a}}$ Daniele Di Lecce, ${ }^{\mathrm{a}}$ Mallory Gobet, ${ }^{\mathrm{b}}$ Stephen Munoz, ${ }^{\mathrm{c}, \mathrm{b}}$ Matthew Devany, ${ }^{\mathrm{d}}$ Steve Greenbaum, b,* and Jusef Hassoun ${ }^{\mathrm{e}, *}$

${ }^{\text {a }}$ Department of Chemistry, Sapienza University of Rome, Piazzale Aldo Moro, 5, 00185, Rome, Italy

${ }^{\mathrm{b}}$ Department of Physics \& Astronomy, Hunter College of the City University of New York, New York, New York 10065, United States

${ }^{c}$ Ph.D. Program in Physics, City University of New York, New York, NY 10016 United States

${ }^{\mathrm{d}}$ Department of Chemistry and Biochemistry, Hunter College of the City University of New York, New York, New York 10065, United States

e Department of Chemical and Pharmaceutical Sciences, University of Ferrara, Via Fossato di Mortara, 44121, Ferrara, Italy

*Corresponding Authors: Jusef.hassoun@unife.it, steve.greenbaum@hunter.cuny.edu

\section{Keywords}

Triethylene glycol dimethyl ether; glyme; electrolyte; lithium battery; pulse field gradient nuclear magnetic resonance

\begin{abstract}
Triethylene glycol dimethyl ether (TREGDME) dissolving lithium trifluoromethane sulfonate $\left(\mathrm{LiCF}_{3} \mathrm{SO}_{3}\right)$ is studied as a suitable electrolyte medium for lithium battery. Thermal and rheological characteristics, transport properties of the dissolved species, and the electrochemical behavior in lithium cell represent the most relevant investigated properties of the new electrolyte. The selfdiffusion coefficients, the lithium transference numbers, the ionic conductivity, and the ion association degree of the solution are determined by pulse field gradient nuclear magnetic resonance and electrochemical impedance spectroscopy. The study sheds light on the determinant role of the lithium nitrate $\left(\mathrm{LiNO}_{3}\right)$ addition for allowing cell operation by improving the electrodes/electrolyte
\end{abstract}


interfaces and widening the voltage stability window. Accordingly, an electrochemical activation procedure of the $\mathrm{Li} / \mathrm{LiFePO}_{4}$ cell using the upgraded electrolyte leads to the formation of stable interfaces at the electrodes surface as clearly evidenced by cyclic voltammetry, impedance spectroscopy, and ex situ scanning electron microscopy. Therefore, the lithium battery employing the TREGDME-LiCF $3 \mathrm{SO}_{3}-\mathrm{LiNO}_{3}$ solution shows a stable galvanostatic cycling, a high efficiency and a notable rate capability upon the electrochemical conditions adopted herein.

\section{Introduction}

Several improvements of the lithium battery throughout the last decades have allowed the recent diffusion of advanced portable electronics, electric vehicles, and smart grids. Lithium-based energy storage systems were first proposed using lithium metal anode as disposable primary batteries able to deliver only one discharge. This simple configuration was later upgraded to the secondary array using reversible intercalation cathodes, and finally to the lithium-ion configuration which can actually perform thousands of cycles by replacing the metal with intercalation anodes. ${ }^{1}$ Despite the higher energy with respect to the lithium-ion battery, the lithium metal system suffers from severe safety issues due to lithium dendrites growth on the anode surface upon prolonged cycling. ${ }^{2}$ This phenomenon may cause internal short circuit $^{3}$ and related thermal runaway, ${ }^{4}$ particularly for the standard lithium battery configuration employing carbonate-based electrolyte and transition metal oxide cathode. ${ }^{5}$ The relevant mitigation of these risks by the lithium-ion battery, using carbon anodes characterized by low working potential vs. $\mathrm{Li}^{+} / \mathrm{Li}^{6}{ }^{6-8}$ has therefore diminished the interest on the metal anode. However extremely attracting features, such as the very high specific capacity (3860 mAh $\left.\mathrm{g}^{-1}\right)$, the lowest electrochemical potential $\left(-3.040 \mathrm{~V}\right.$ vs. SHE), and the low density $\left(0.59 \mathrm{~g} \mathrm{~cm}^{-3}\right){ }^{2}$ have periodically renewed the interest on the lithium metal, in particular in view of its possible use in rechargeable batteries having alternative configuration, such as $\mathrm{Li}-\mathrm{S}^{9-12}$ and $\mathrm{Li}-\mathrm{O}_{2}{ }^{13-16}$ Indeed, conventional graphite anodes have specific capacity limited to $372 \mathrm{mAh} \mathrm{g}^{-1}$, working voltage of 0.2 vs. $\mathrm{Li}^{+} / \mathrm{Li}$, and density of $2.25 \mathrm{~g} \mathrm{~cm}^{-3}$. Considering a four-fold lithium excess, which is necessary to 
reach a sufficient cycle life of lithium metal cells, the practical specific capacity of the lithium metal anode is estimated as $965 \mathrm{mAh} \mathrm{g}^{-1}$, i.e., higher than graphite. ${ }^{17}$ Furthermore, the use of lithium metal anode allows to remove the $\mathrm{Cu}$ anode support, which has high density of $8.96 \mathrm{~g} / \mathrm{cm}^{3}$, and to balance the first cycle irreversible capacity of the cathode. Therefore, the employment of the lithium anode has been taken into account in recent works reporting novel cell compositions. ${ }^{18-21}$ Polymer or solid electrolytes, such as polyethylene oxide $(\mathrm{PEO})^{22,23}$, polyethylene carbonate (PEC), ${ }^{24}$ or glass types,${ }^{25,26}$ might allow the use of lithium metal. Despite the very modest flammability and the limited lithium dendrites growth, these electrolytes have revealed low ionic conductivity and high operating temperatures, which hinder the room-temperature application. ${ }^{27,28}$ Poly(ethylene glycol) dimethyl ethers having short $\mathrm{R}_{1} \mathrm{O}\left(\mathrm{CH}_{2} \mathrm{CH}_{2} \mathrm{O}\right)_{n} \mathrm{R}_{2}$ chain, called end-capped glymes, are aprotic liquid solvents for lithium salts characterized by suitable electrochemical features for lithium batteries, low volatility, and high flash point. ${ }^{29-31}$ However, glyme-based electrolytes have shown poor passivation properties of the lithium metal surface, which lead to remarkable increase of cell polarization and interface resistance upon cycling, as well as to excessive electrolyte decomposition. ${ }^{32-34}$ The addition of lithium nitrate $\left(\mathrm{LiNO}_{3}\right)$ may actually improve the lithium/electrolyte interface by formation upon cycles of a stable passivation film containing nitrate moieties, such as $\mathrm{RCH}_{2} \mathrm{NO}_{2}, \mathrm{LiN}_{\mathrm{x}} \mathrm{O}_{\mathrm{y}}$ and $\mathrm{Li}_{\mathrm{x}} \mathrm{N},{ }^{35}$ thus leading to proper battery operation and limiting dendrite formation. ${ }^{36-38}$ Glyme-based electrolytes have been widely investigated for $\mathrm{Li}-\mathrm{S}^{10,31,39-45}$ and $\mathrm{Li}-\mathrm{O}_{2} ;{ }^{46-50}$ however, they may be also used for intercalation cathode materials, although limited papers demonstrated good cell performances. ${ }^{51,52}$

The beneficial effect of $\mathrm{LiNO}_{3}$ was widely investigated in lithium-sulfur batteries using glyme-based electrolytes. Indeed, $\mathrm{LiNO}_{3}$ can protect the lithium electrode surface from parasitic reactions by forming a passivation film, which avoids the polysulfide shuttle phenomenon, i.e., the lithium metal corrosion by polysulfide species dissolved in the electrolyte solution. ${ }^{53,54}$ Such a protective solid electrolyte interphase (SEI) starts growing immediately upon Li-S cell assembly, by precipitation of $\mathrm{Li}_{x} \mathrm{NO}_{y}$ and $\mathrm{Li}_{x} \mathrm{SO}_{y}$ species blocking the electron transfer from lithium metal to the polysulfides dissolved in the solution and ensuring at the same time $\mathrm{Li}^{+}$conduction. ${ }^{55}$ Thus, $\mathrm{LiNO}_{3}$ 
enables stable cycling of Li-S cells by formation of a suitable SEI on the anode. However, the irreversible reduction of $\mathrm{NO}_{3}{ }^{-}$anions on the cathode side at potentials lower than $1.8 \mathrm{~V} \mathrm{vs.} \mathrm{Li}^{+} / \mathrm{Li}$ leads to (i) limited electrode kinetics likely due to precipitation of reduction products on the cathode surface, and (ii) nitrate consumption. In particular, XPS measurements revealed polymerization products over the cathode, which have been related in literature to possible nucleophilic attack of the solvent molecules by $\mathrm{O}^{2-}$ formed during reduction of nitrate to nitrite species. ${ }^{38,56,57}$ On the other hand, we reported for the first time in two recent papers that $\mathrm{LiNO}_{3}$ allows the use of glyme$\mathrm{LiCF}_{3} \mathrm{SO}_{3}$-based electrolytes in lithium metal batteries with olivine cathodes ${ }^{58,59}$ Furthermore, the reduction down to $1.8 \mathrm{~V}$ upon the first discharge has revealed a crucial effect on the cell stabilization. Indeed, the cells without $\mathrm{LiNO}_{3}$ showed very poor electrochemical activity and fast capacity decay, while those ones containing $\mathrm{LiNO}_{3}$ exhibited stable behavior upon cycling after an electrochemical reduction performed by decreasing the potential below $1.8 \mathrm{~V} \mathrm{vs.} \mathrm{Li}^{+} / \mathrm{Li}$. However, this unexpected behavior needed further investigation, which is therefore one of the aims of the present paper.

Therefore, we report herein the full study of an electrolyte solution formed by dissolving lithium triflate $\left(\mathrm{LiCF}_{3} \mathrm{SO}_{3}\right)$ in new end-capped glyme, i.e., triethylene glycol dimethyl ether (TREGDME, $\mathrm{CH}_{3}\left(\mathrm{OCH}_{2} \mathrm{CH}_{2}\right)_{3} \mathrm{OCH}_{3}$ ), which is characterized by a lower viscosity, thus higher conductivity, with respect to previously studied glymes. Thermogravimetric analysis (TGA), differential scanning calorimetry (DSC), viscosity analysis, as well as pulse field gradient nuclear magnetic resonance (PFG NMR) and electrochemical impedance spectroscopy (EIS), are employed to determine thermal and rheological properties, the mobility of the dissolved species and the electrochemical characteristics of the electrolyte, respectively. The paper reports a deep investigation of the self-diffusion coefficient, ionic conductivity, lithium transference number, and ionic association degree and suggests the solution as suitable electrolyte medium in a lithium metal cell using a $\mathrm{LiFePO}_{4}$ cathode prepared in our laboratory. ${ }^{60}$ Particular care is devoted to the study of both $\mathrm{LiNO}_{3}$ addition effects and the electrochemical activation procedure before cell cycling, which ensure the formation of a stable electrode/electrolyte interface over anode and cathode. The study of the 
electrode/electrolyte interface is carried out by lithium stripping/deposition, voltammetry, electrochemical impedance spectroscopy (EIS), as well as by ex situ scanning electrode microscopy (SEM). Accordingly, the formation of the SEI at the electrodes surface promoted by the condition adopted in this work represents a key parameter allowing proper operation of the lithium cell. Then, the $\mathrm{Li} / \mathrm{LiCF}_{3} \mathrm{SO}_{3}-\mathrm{TREGDME} \mathrm{LiNO}_{3} / \mathrm{LiFePO}_{4}$ battery is studied by galvanostatic cycling at several current rates, revealing suitable performances.

\section{Experimental}

\section{Electrolyte and cathode preparation}

Triethylene glycol dimethyl ether (TREGDME, $\mathrm{CH}_{3}\left(\mathrm{OCH}_{2} \mathrm{CH}_{2}\right)_{3} \mathrm{OCH}_{3}$, Sigma-Aldrich) was dried under molecular sieves $(5 \AA)$ until the water content was below $10 \mathrm{ppm}$, as determined by using the Karl Fischer titration instrument (831 Karl Fisher Coulometer, Metrohm). Lithium trifluoromethanesulfonate (lithium triflate, $\mathrm{LiCF}_{3} \mathrm{SO}_{3}$, Sigma-Aldrich) and lithium nitrate $\left(\mathrm{LiNO}_{3}\right.$, Sigma-Aldrich) were dried overnight under vacuum at $80^{\circ} \mathrm{C}$ before use. The electrolyte was prepared by dissolving $\mathrm{LiCF}_{3} \mathrm{SO}_{3}$ in TREGDME in $1 \mathrm{~mol} \mathrm{~kg}^{-1}$ concentration with respect to the solvent (solution indicated by the acronym TREG-LiCF $3 \mathrm{SO}_{3}$ ). A second electrolyte solution was prepared by dissolving $\mathrm{LiCF}_{3} \mathrm{SO}_{3}$ and $\mathrm{LiNO}_{3}$ in TREGDME; both salts were used in $1 \mathrm{~mol} \mathrm{~kg}^{-1}$ concentration with respect to the solvent (solution indicated by the acronym $\mathrm{TREG}-\mathrm{LiCF}_{3} \mathrm{SO}_{3}-\mathrm{LiNO}_{3}$ ). $\mathrm{The}$ electrolyte preparation was carried out in an argon-filled glovebox with moisture and oxygen content lower than $1 \mathrm{ppm}$. The structure representation by ball-and-stick model of the species forming the TREG-LiCF $\mathrm{SO}_{3}$ and TREG-LiCF $3 \mathrm{SO}_{3}-\mathrm{LiNO}_{3}$ electrolytes is shown in Fig. S1 of the Supporting Information.

The $\mathrm{LiFePO}_{4}$ (LFP) powder was synthesized by solvothermal treatment and following hightemperature annealing in inert atmosphere, as reported in a previous paper. ${ }^{60}$ The cathode film was prepared mixing the active material, poly(vinylidene fluoride-hexafluoropropylene) (PVdF-HFP copolymer, Kynar Flex 2801) as binder, and Super P Carbon (Timcal) as conductive additive in the 
ratio 80:10:10\% w/w in Tetrahydrofuran (THF, Sigma-Aldrich). The slurry thus obtained was casted on either aluminum foil or carbon cloth current collector by doctor blade. The carbon cloth support was used for cycling test at constant current rate, while the aluminum support was used for cyclic voltammetry and rate capability tests. The carbon cloth electrode supports may enhance the electrochemical performances of olivine cathode materials synthesized in our laboratory, particularly in terms cycling stability. This phenomenon is likely related to the improved electric contact between active material particles and current collector as well as to the higher electrode contact area of carbon cloth with respect to $\mathrm{Al}$ foil. ${ }^{59}$ Therefore, we used the carbon cloth for cycling test at a constant rate. Beside cycle life, cyclic voltammetry and rate capability tests were performed in order to detect the electrochemical processes due to $\mathrm{LiFePO}_{4}$ and $\mathrm{LiNO}_{3}$, hence we considered the aluminum support as the most suitable current collector for evaluation. The electrode films were dried overnight under vacuum at $110^{\circ} \mathrm{C}$, cut in the form of $10 \mathrm{~mm}$ dimeter disks, and brought in an argon-filled glovebox before cell assembling. The electrodes had mass loading of about $4 \mathrm{mg} \mathrm{cm}^{-2}$.

\section{Materials characterization}

The thermal properties of $\mathrm{TREG}-\mathrm{LiCF}_{3} \mathrm{SO}_{3}$ were evaluated by differential scanning calorimetry (DSC). The samples were put in a sealed Al crucible in an argon-filled glovebox for DSC; the measurement was performed from $20{ }^{\circ} \mathrm{C}$ to $-90{ }^{\circ} \mathrm{C}$ with a cooling rate of $5{ }^{\circ} \mathrm{C} \min ^{-1}$. Thermogravimetric analyses (TGA) of TREGDME, TREG-LiCF $3 \mathrm{SO}_{3}$, and TREG-LiCF $3 \mathrm{SO}_{3}-\mathrm{LiNO}_{3}$ were carried out by using a TG209 F1 Libra, Netzsch, instrument. The samples were heated at a rate of $10{ }^{\circ} \mathrm{C} \mathrm{min}-1$ from room temperature to $600{ }^{\circ} \mathrm{C}$ under a nitrogen purge $\left(40 \mathrm{~mL} \mathrm{~min}^{-1}\right)$. The samples were hermetically sealed inside a dry room (dew point $<-70{ }^{\circ} \mathrm{C}$ ) in aluminum pans, which were punched under nitrogen atmosphere just before the measurement.

The viscosity of TREGDME, TREG-LiCF $3 \mathrm{SO}_{3}$, and TREG-LiCF $3 \mathrm{SO}_{3}-\mathrm{LiNO}_{3}$ was evaluated at various temperatures in a dry room (dew point $<-70{ }^{\circ} \mathrm{C}$ ) through an Anton-Paar Physica MCR102 rheometer, by applying constant shear rates and using a Peltier system for cooling/heating. The 
measurements were performed every $10{ }^{\circ} \mathrm{C}$ upon sample heating after 15 min of equilibration at constant temperature.

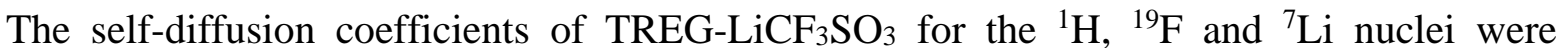
investigated with a Bruker 400 Advance III NMR spectrometer. Screw-cap gas-tight NMR tubes were used. The measurements were carried out using a double stimulated echo sequence with pulsed field gradients (PFG) in order to suppress convection; data were collected every $10{ }^{\circ} \mathrm{C}$ from $20{ }^{\circ} \mathrm{C}$ to 80 ${ }^{\circ} \mathrm{C}$ for each nucleus. Gradient pulse duration $(\delta)$ of $1.4-4 \mathrm{~ms}$, diffusion delay $(\Delta)$ of $200-400 \mathrm{~ms}$, and a gradient pulse strength increased linearly in 32 steps from 1 to $45 \mathrm{G} \mathrm{cm}^{-1}$ were used. A longitudinal eddy-current delay (LED) of $5 \mathrm{~ms}$ was used to avoid eddy current effects. The selfdiffusion coefficients were calculated using equation (1) by fitting the integral of the signal obtained as function of the gradient strength:

$$
I=I_{0} e^{-D \gamma^{2} g^{2} \delta^{2}\left(\Delta-\frac{\delta}{3}\right)}
$$

where I is the signal integral, $\mathrm{D}$ is the self-diffusion coefficient, $\gamma$ is the gyromagnetic ratio of the studied nucleus, $\mathrm{g}$ is the gradient pulse strength, $\delta$ is the gradient pulse duration and $\Delta$ is the diffusion delay. The error on the self-diffusion coefficient is about $3-5 \% .^{61}$ The lithium transference number was obtained by the following equation (2).

$$
t^{+}=\frac{D_{L i}}{D_{L i}+D_{C F_{3} S O_{3}}}
$$

where $\mathrm{t}^{+}$is the transference number of the cation, $\mathrm{D}_{\mathrm{Li}}$ is the self-diffusion coefficient of lithium, and $\mathrm{D}_{\mathrm{CF}_{3} \mathrm{SO}_{3}}$ is the self-diffusion coefficient of the $\mathrm{CF}_{3} \mathrm{SO}_{3}{ }^{-}$anion.

Ionic conductivity was measured by impedance spectroscopy (EIS) using $10 \mathrm{mV}$ signal amplitude in the $100 \mathrm{kHz}-100 \mathrm{mHz}$ frequency range through a VSP (Biologic) instrument. The measurements were performed every $10{ }^{\circ} \mathrm{C}$ from $30{ }^{\circ} \mathrm{C}$ to $80{ }^{\circ} \mathrm{C}$ on symmetrical stainless steel/electrolyte/stainless steel 2032-coin cell, using a Teflon ring (thickness $=500 \mu \mathrm{m}$ ) as the separator in order to fix the cell constant. The conductivity values obtained by EIS were compared 
with those calculated using the self-diffusion coefficient $\left(\delta_{N M R}\right)$ through the Nernst-Einstein equation (3):

$$
\delta_{N M R}=\frac{F^{2}[C]}{R T}\left(D_{L i}+D_{C F_{3} S O_{3}}\right)
$$

where $\delta_{\text {NMR }}$ is the conductivity determined by the NMR, F is the Faraday constant $(96485 \mathrm{C}),[\mathrm{C}]$ is the concentration of the salt in the electrolyte $\left(\mathrm{mol} \mathrm{cm}^{-3}\right), \mathrm{R}$ is the ideal-gas constant $\left(8.314472 \mathrm{~J} \mathrm{~K}^{-1}\right.$ $\mathrm{mol}^{-1}$ ), $\mathrm{T}$ is the temperature (K), $\mathrm{D}_{\mathrm{Li}}$ and $\mathrm{D}_{\mathrm{CF}_{3} \mathrm{SO}_{3}}$ are the corresponding self-diffusion coefficient. The ion association degree was derived from equation (4):

$$
\alpha=\left(1-\frac{\delta_{E I S}}{\delta_{N M R}}\right)
$$

$\alpha$ is the ion association degree, $\delta_{\text {NMR }}$ and $\delta_{\text {EIS }}$ are the conductivity by PFG NMR and EIS, respectively.

Lithium stripping-deposition tests were carried out on TREG- $\mathrm{LiCF}_{3} \mathrm{SO}_{3}$ and TREG$\mathrm{LiCF}_{3} \mathrm{SO}_{3}-\mathrm{LiNO}_{3}$ solutions using Swagelok-type symmetrical cell with a Whatman® separator, by applying constant current of $0.1 \mathrm{~mA} \mathrm{~cm}^{-1}$ with step duration of $1 \mathrm{~h}$ through a Maccor 4000 series Battery Test System. The anodic stability of TREG-LiCF $3 \mathrm{SO}_{3}$ and TREG-LiCF $3 \mathrm{SO}_{3}-\mathrm{LiNO}_{3}$ was investigated by linear sweep voltammetry at $0.1 \mathrm{mV} \mathrm{s}^{-1}$ on Swagelok-type 3-electrodes cells with lithium metal for the counter and reference electrodes, and carbon-coated on aluminum foil as working electrode. Carbon-coated $\mathrm{Al}$ electrode allows determination of the actual electrochemical anodic stability window, which may be underestimated with $\mathrm{Ni}$ or Pt working electrodes. The same cell configuration, was used for cyclic voltammetry measurements; the working electrode reasonably reproduces the electrolyte behavior on composite cathodes, usually formed by active material, conductive carbon and polymer binder. The tests were performed on TREG-LiCF $3 \mathrm{SO}_{3}$ and TREG$\mathrm{LiCF}_{3} \mathrm{SO}_{3}-\mathrm{LiNO}_{3}$ to evaluate electrolyte behavior and the effect of $\mathrm{LiNO}_{3}$ addition, at a scan rate of $0.1 \mathrm{mV} \mathrm{s}^{-1}$ within the $1-4.3 \mathrm{~V}$ vs. $\mathrm{Li}^{+} / \mathrm{Li}$ potential range for the first cycle, and within the $2-4.3 \mathrm{~V}$ vs. $\mathrm{Li}^{+} / \mathrm{Li}$ potential range for the subsequent cycles. Further voltammetry experiments were carried out employing LFP (on aluminum support) as the working electrode, with a scan rate of $0.1 \mathrm{mV} \mathrm{s}^{-1}$ 
within the $1-4.3 \mathrm{~V}$ vs. $\mathrm{Li}^{+} / \mathrm{Li}$ potential range for the first cycle, and within the $2-4.3 \mathrm{~V} \mathrm{vs}^{-\mathrm{Li}^{+} / \mathrm{Li}}$ potential range for the subsequent cycles. The voltammetry measurements were performed though a VersaSTAT MC Princeton Applied Research - AMETEK potentiostat. The lithium/electrolyte interfacial stability of TREG-LiCF $3 \mathrm{SO}_{3}$ and TREG-LiCF $3 \mathrm{SO}_{3}-\mathrm{LiNO}_{3}$ were evaluated by performing EIS tests on symmetrical lithium/electrolyte/lithium Swagelok-type cells with a Whatman ${ }^{\circledR}$ separator, using $10 \mathrm{mV}$ signal amplitude in the $500 \mathrm{kHz}-200 \mathrm{mHz}$ frequency range through a VersaSTAT MC Princeton Applied Research-AMETEK potentiostat. The impedance spectra were analyzed by nonlinear least-square (NLLS) fit using the Boukamp software; ${ }^{62,63}$ the fit reliability was confirmed by chi-square $\left(\chi^{2}\right)$ values lower than $10^{-4}$. The equivalent circuit adopted for the Nyquist plot (Figs. S1 and S2 in the Supporting Information) was $\mathrm{R}_{\mathrm{a}}\left(\mathrm{R}_{\mathrm{i}} \mathrm{Q}_{\mathrm{i}}\right)_{\mathrm{n}} \mathrm{Q}_{\mathrm{b}}$, where $\mathrm{R}$ represents a resistance and Q a constant phase element (CPE). Galvanostatic cycling tests were performed through a Maccor 4000 series Battery Test System on Li/TREG-LiCF $3 \mathrm{SO}_{3}-\mathrm{LiNO}_{3} / \mathrm{LFP}$ Swagelok-type two-electrode cells with a Whatman ${ }^{\circledR}$ separator. The cells were electrochemically activated by 4 galvanostatic cycles at $\mathrm{C} / 5$ rate $\left(1 \mathrm{C}=170 \mathrm{mAhg}^{-1}\right)$; the first discharge was performed by decreasing the voltage below $2 \mathrm{~V}$ and limiting the time to $5.15 \mathrm{~h}$, in order to form a stable solid electrolyte interphase (SEI) layer at the electrode surface (see the Supporting Information). The subsequent cycles were performed within the $2-4 \mathrm{~V}$ voltage range at $\mathrm{C} / 5$ rate for test at single current, and at $\mathrm{C} / 10, \mathrm{C} / 5, \mathrm{C} / 3$, $\mathrm{C} / 2,1 \mathrm{C}$, and $2 \mathrm{C}$ for rate capability test $\left(1 \mathrm{C}=170 \mathrm{mAhg}^{-1}\right) . \mathrm{SEM}$ Zeiss EVO 40 with a thermionic electron gun equipped by LaB6 crystal was employed to study the morphology of the electrodes at various cycling stages.

\section{Result and discussion}

TREG- $\mathrm{LiCF}_{3} \mathrm{SO}_{3}$ is investigated by TGA and DSC for determining key parameters for battery application, such as thermal characteristics and freezing point. Fig. 1a, reporting TGA under nitrogen flow, reveals weight loss starting at about $75^{\circ} \mathrm{C}$, likely due to evaporation of TREGDME, which represents a first indication of the upper operating temperature of the electrolyte. ${ }^{64} \mathrm{~A}$ further massive 
weight loss is observed above $200{ }^{\circ} \mathrm{C}$. This could be related to the boiling of TREGDME (which falls in the $224-227^{\circ} \mathrm{C}$ range). Then, weight losses at higher temperatures reveal salt decomposition. ${ }^{31}$ Figure S2a of the Supporting Information compares the TGA profiles of pristine TREGDME, TREG$\mathrm{LiCF}_{3} \mathrm{SO}_{3}$, and $\mathrm{TREG}-\mathrm{LiCF}_{3} \mathrm{SO}_{3}-\mathrm{LiNO}_{3}$. The pure solvent exhibits a weight loss beginning at $60{ }^{\circ} \mathrm{C}$ due to evaporation promoted by the $\mathrm{N}_{2}$ flow, followed by a further weight loss above $200{ }^{\circ} \mathrm{C}$ indicating the boiling point. TREG- $\mathrm{LiCF}_{3} \mathrm{SO}_{3}$ and $\mathrm{TREG}-\mathrm{LiCF}_{3} \mathrm{SO}_{3}-\mathrm{LiNO}_{3}$ exhibit a similar trend upon heating and a higher thermal stability than pristine TREGDME. Fig. 1b shows the DSC cooling profile of $\mathrm{TREG}-\mathrm{LiCF}_{3} \mathrm{SO}_{3}$ from room temperature to $-90{ }^{\circ} \mathrm{C}$, performed in order to determine the freezing point of the electrolyte. The curve reveals an exothermic crystallization peak at $-60{ }^{\circ} \mathrm{C}$ which suggests the lowest temperature suitable for the application of the electrolyte in lithium cell. In summary, the thermal properties revealed by Fig. 1 suggests a possible operating range extending from $-60{ }^{\circ} \mathrm{C}$ to $75^{\circ} \mathrm{C}$, which exceeds that one of conventional carbonate-based electrolytes..$^{65}$

Fig. 1c reports the viscosity profile of $\mathrm{TREG}-\mathrm{LiCF}_{3} \mathrm{SO}_{3}$ studied within temperature ranging from $-10{ }^{\circ} \mathrm{C}$ to $80^{\circ} \mathrm{C}$. The figure reveals the expected decreasing trend by raising temperature. The TREG-LiCF $3 \mathrm{SO}_{3}$ electrolyte has viscosity of about $5 \mathrm{mPa}$ s at $20{ }^{\circ} \mathrm{C}$, which is consider suitable value for battery application. Viscosity measurements on TREGDME solvent and TREG-LiCF $3 \mathrm{SO}_{3}-\mathrm{LiNO}_{3}$ electrolyte have been also carried out to evaluate the changes due to salt addition. Figure S2b of the Supporting Information shows that the viscosity increases in the whole range of temperature due to addition of $\mathrm{LiCF}_{3} \mathrm{SO}_{3}$ and $\mathrm{LiNO}_{3}$, with values at $20^{\circ} \mathrm{C}$ of 2.3 and $11.7 \mathrm{mPa}$ s for TREGDME and TREG-LiCF $\mathrm{SO}_{3}-\mathrm{LiNO}_{3}$, respectively. 


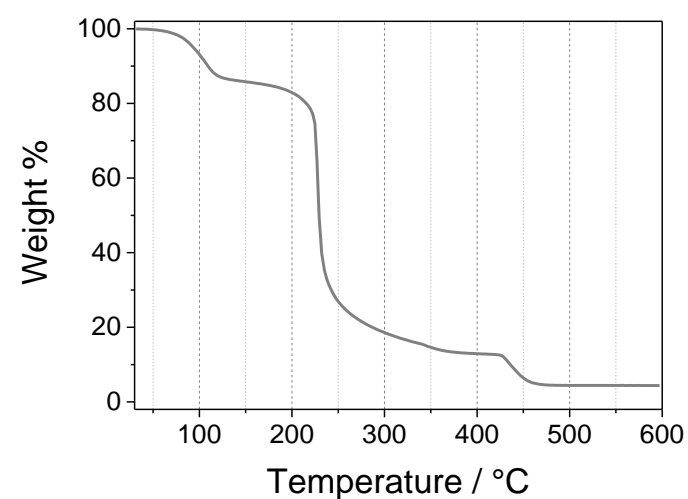

(a)

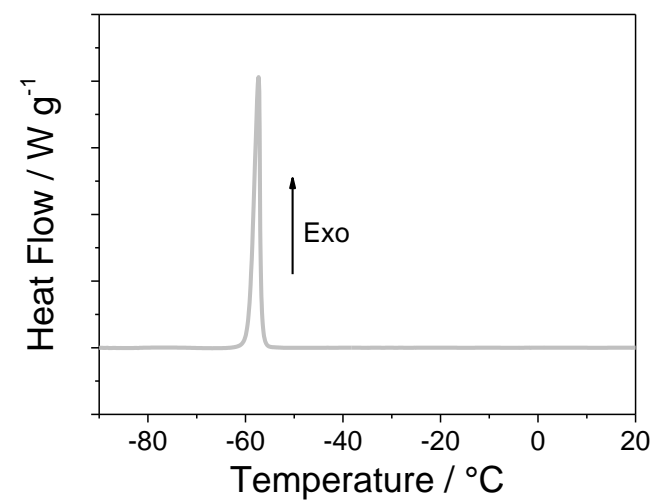

(b)

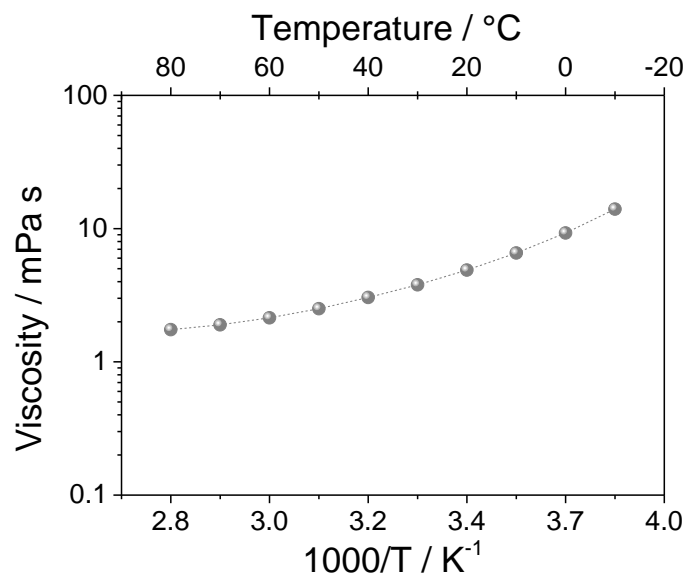

(c)

Figure 1. Thermal properties of $\mathrm{TREG}-\mathrm{LiCF}_{3} \mathrm{SO}_{3}$ as studied by (a) thermogravimetric analysis (TGA) under nitrogen purge $\left(40 \mathrm{~mL} \mathrm{~min}^{-1}\right)$ at $10{ }^{\circ} \mathrm{C} \mathrm{min}^{-1}$ heating rate from room temperature to 600 ${ }^{\circ} \mathrm{C}$ and (b) differential scanning calorimetry (DSC) under Ar atmosphere at $5{ }^{\circ} \mathrm{C} \min ^{-1}$ cooling rate

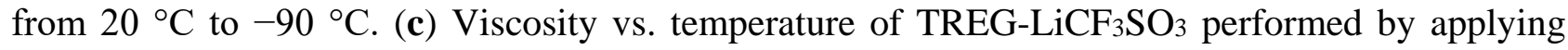
constant shear rates and collecting data every $10{ }^{\circ} \mathrm{C}$ after 15 minutes of thermal stabilization; temperature range from $-10{ }^{\circ} \mathrm{C}$ to $80{ }^{\circ} \mathrm{C}$. (See the experimental section for sample acronym).

The transport properties of TREG-LiCF $3 \mathrm{SO}_{3}$ were investigated by coupling PFG NMR and EIS in the temperature range from $20^{\circ} \mathrm{C}$ to $80^{\circ} \mathrm{C}$, i.e., the typical window for battery applications. Fig. 2 shows the results in terms of self-diffusion coefficient (Fig. 2a), lithium transference number 
(Fig. 2b), conductivity (Fig. 2c), and ion association degree (Fig 2.d). The PFG NMR of ${ }^{1} \mathrm{H},{ }^{7} \mathrm{Li}$ and ${ }^{19} \mathrm{~F}$ nuclei indicates the same increasing trend of self-diffusion coefficient of TREGDME solvent, $\mathrm{Li}^{+}$ and $\mathrm{CF}_{3} \mathrm{SO}_{3}{ }^{-}$salt ions, respectively, with increasing temperature (Fig. 2a); however, the TREGDME chains exhibit higher mobility in the whole temperature range with respect to the ion species, which show similar value of the coefficient. The activation energies related to the self-diffusion process, reported in inset of Fig. 2a, are comparable for TREGDME chains and anions, while the small lithium ion shows a slightly higher activation energy, however within the experimental error of the test (see experimental section). On the other hand, a higher activation energy for lithium ions may be reasonably expected by the strong interaction with the other species promoted by its high charge density. The lithium transference number $\left(\mathrm{t}^{+}\right)$was calculated by equation (2) as the amount of charge carried by lithium cations with respect to the total charge and reported in Fig. 2b. The figure shows a $\mathrm{t}^{+}$value of about 0.5 within the whole temperature range, which may be considered a suitable value for lithium battery application. The ionic conductivity of the electrolyte was calculated from the selfdiffusion coefficient data estimated from PFG NMR by applying the equation (3) (see the experimental section for further details) and is compared with the data measured by EIS in Fig. 2c. Remarkably, the two methods provide conductivity values having difference of about one order of magnitude, as already reported in literature works. ${ }^{58,66,67}$ This discrepancy is due to the differences between the two techniques: PFG NMR overestimates the ionic conductivity since it reveals the motion of all selected atoms within the electrolyte, i.e., single ions, ionic couples, and multiple associated ions, while EIS indicates the actual ionic conductivity ascribed to the net charge flow. ${ }^{58,66,67}$ In fact, this high degree of ionic association is at least partially responsible for the observation that the apparent $\mathrm{Li}^{+}$transference numbers are close to 0.5 . Indeed, the conductivity measured by EIS has a stable value of about $1.9 * 10^{-3} \mathrm{~S} \mathrm{~cm}^{-1}$ within the whole temperature range, which well matches the battery application requirements, while the conductivity derived from selfdiffusion coefficient exhibit slightly increasing trend, with a value of the order of $10^{-2} \mathrm{~S} \mathrm{~cm}^{-1}$. 


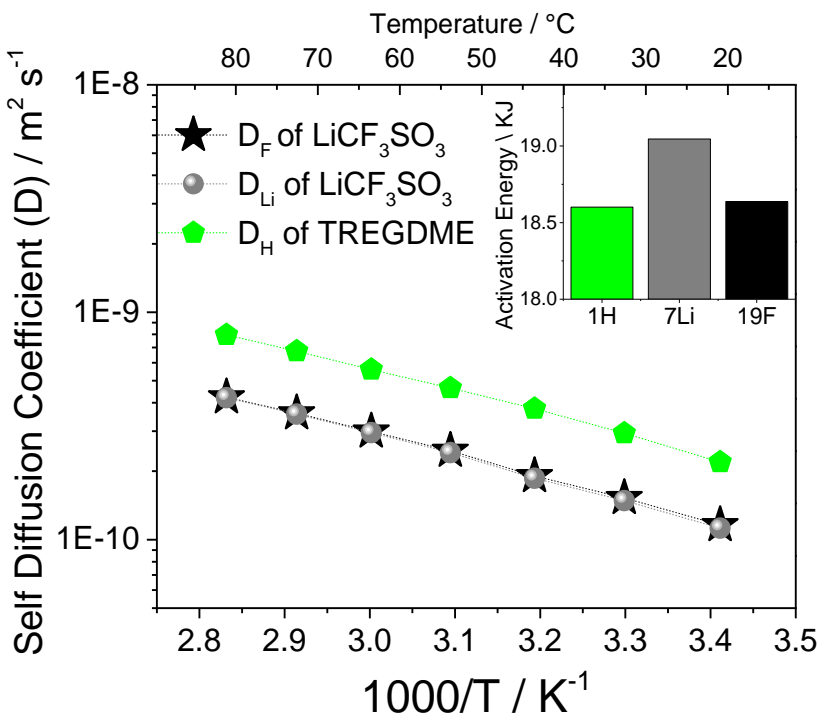

(a)

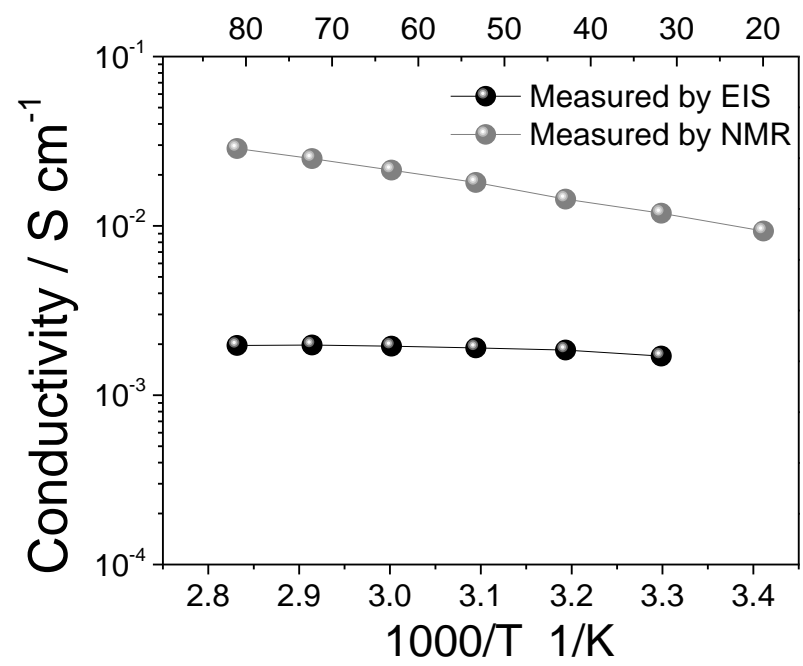

(c)

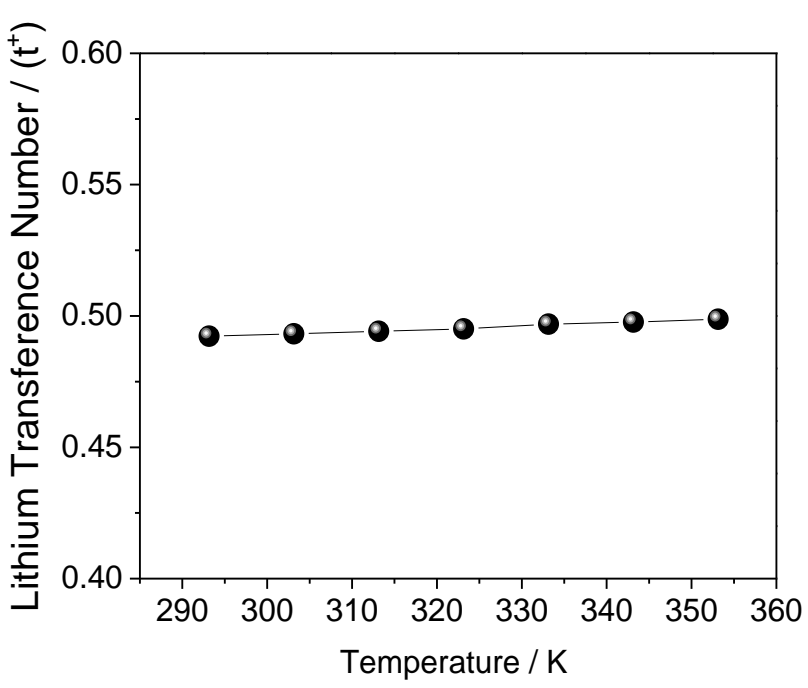

(b)

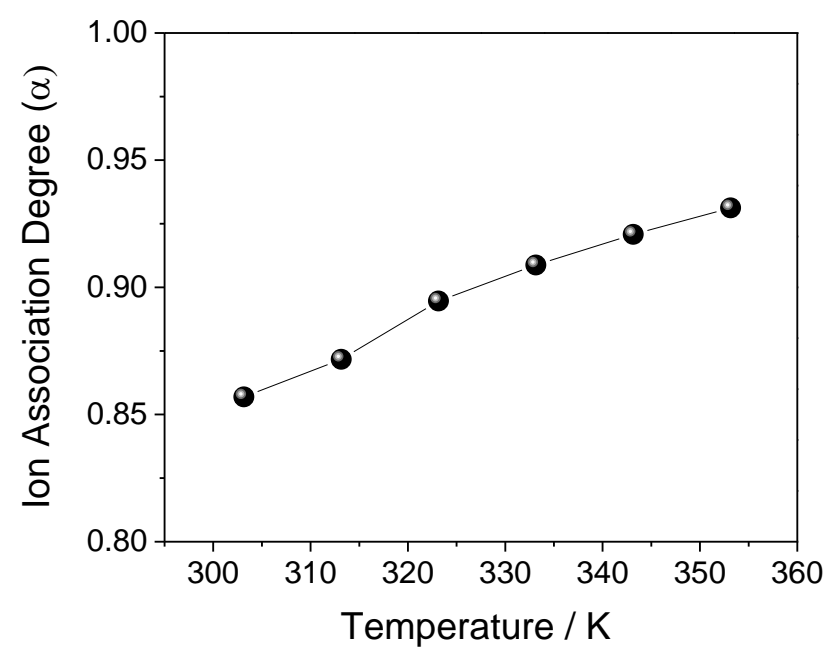

(d)

Figure 2. (a) Self-diffusion coefficient of the ${ }^{1} \mathrm{H}$, ${ }^{9} \mathrm{~F}$, and ${ }^{7} \mathrm{Li}$ nuclei of TREG-LiCF $3 \mathrm{SO}_{3}$ (see the experimental section for sample acronym) as determined by PFG NMR in the $20-80{ }^{\circ} \mathrm{C}$ temperature range; figure inset: self-diffusion activation energies for each nucleus $\left({ }^{1} \mathrm{H},{ }^{9} \mathrm{~F}\right.$, and $\left.{ }^{7} \mathrm{Li}\right)$ extrapolated from the self-diffusion coefficient in the Arrhenius plot. (b) Lithium transference number calculated from the self-diffusion coefficient data by equation (2) within the $20-80{ }^{\circ} \mathrm{C}$ temperature range. (c) Ionic conductivity obtained by EIS (black line) and calculated from the self-diffusion coefficient data by equation (3) within the $20-80{ }^{\circ} \mathrm{C}$ temperature range. (d) Ion association degree between $\mathrm{Li}^{+}$ cation and $\mathrm{CF}_{3} \mathrm{SO}_{3}{ }^{-}$anion calculated by using equation (4) from the ionic conductivity data obtained by EIS and PFG NMR.

According to the above discussion, the conductivity data were used to calculate the ion association degree (Fig. 2d) by applying the equation (4). The slight increase of the association degree with increasing temperature reflects free ions recombination in pairs or complexes, which leads to a 
lower number of charge carriers at higher temperature. This phenomenon, already reported in literature for ether-based electrolytes, has been attributed to a solvent dielectric constant drop due to temperature increase, which causes a decrease of the glyme solvation power. ${ }^{58}$ Despite increased ion association degree, the stable values of the actual ionic conductivity measured by EIS (Fig. 2c) is attributed to a simultaneous solvent viscosity decrease at the higher temperature, leading to a better mobility of the charge carriers.

We have shown in a previous publication stability issues affecting the electrode/electrolyte interface in lithium cell using insertion electrode and long chain glyme electrolyte. ${ }^{58}$ The study, principally focusing on electrolyte applicability, has evidenced that these issues may be strongly mitigated by the addition of $\mathrm{LiNO}_{3}$ to the electrolyte, despite negligible change of the thermal characteristic and viscosity increase (Fig. S2 in the Supporting Information). The $\mathrm{LiNO}_{3}$ addition partially affect the ionic conductivity of the solution. Indeed, Fig. S2c of the Supporting Information reveals for both TREG-LiCF $3 \mathrm{SO}_{3}$ and TREG-LiCF $3 \mathrm{SO}_{3}-\mathrm{LiNO}_{3}$ ionic conductivity of the order of $10^{-3} \mathrm{~S} \mathrm{~cm}^{-1}$ within the investigated temperature range.

The effect of $\mathrm{LiNO}_{3}$ addition is further studied in the present paper by galvanostatic measurements, impedance spectroscopy and voltammetry. Fig. 3 shows a comparison of the electrochemical features of TREG-LiCF $3 \mathrm{SO}_{3}$ and $\mathrm{TREG}_{-} \mathrm{LiCF}_{3} \mathrm{SO}_{3}-\mathrm{LiNO}_{3}$ in terms of lithium/electrolyte interface stability throughout lithium deposition/dissolution by galvanostatic cycling (Fig. 3a), anodic stability window (Fig. 3b), and lithium/electrolyte interface resistance trend upon storage of $\mathrm{Li} / \mathrm{Li}$ symmetrical cell (Fig. 3c). Fig. 3a reveals for TREG-LiCF $3 \mathrm{SO}_{3}$ a remarkable overvoltage increase over six days of cycling, which indicates poor stability of lithium metal anode in the pristine electrolyte. On the other hand, the $\mathrm{LiNO}_{3}$ addition stabilizes the lithium/electrolyte interface; indeed, the TREG- $\mathrm{LiCF}_{3} \mathrm{SO}_{3}-\mathrm{LiNO}_{3}$ cell maintains a polarization as low as $20 \mathrm{mV}$ for up to 12 days of cycles. $\mathrm{LiNO}_{3}$ has a beneficial effect on the anodic stability too, as shown by the linear sweep voltammetries of Fig. 3b. TREG-LiCF $3 \mathrm{SO}_{3}$ exhibits a current onset of about $5 \mu \mathrm{A} \mathrm{cm}{ }^{-2}$ at 3.55 $\mathrm{V}$ vs. $\mathrm{Li}^{+} / \mathrm{Li}$ and undergoes further oxidation above $4 \mathrm{~V}$ vs. $\mathrm{Li}^{+} / \mathrm{Li}$, as revealed by rising current at 
higher potential. Meanwhile, TREG-LiCF $3 \mathrm{SO}_{3}-\mathrm{LiNO}_{3}$ shows a current peak at about $3.72 \mathrm{~V}$ vs. $\mathrm{Li}^{+} / \mathrm{Li}$, likely associated with $\mathrm{LiNO}_{3}$, and only minor decomposition processes below $4.5 \mathrm{~V} \mathrm{vs.} \mathrm{Li}^{+} / \mathrm{Li}$, followed by remarkable current increasing at $4.6 \mathrm{~V}$ vs. $\mathrm{Li}^{+} / \mathrm{Li}$. Therefore, the anodic stability of the electrolyte well matches the application in a lithium battery using LFP cathode characterized by working voltage of $3.45 \mathrm{~V}$ vs. $\mathrm{Li}^{+} / \mathrm{Li}$ (see following paragraphs). ${ }^{68}$

The stability of the lithium/electrolyte interface under static condition, i.e., the chemical stability, is investigated by EIS tests carried out during 28 days of storage in symmetrical Li/Li cell without current flowing. Fig. S3 in the Supporting Information shows the Nyquist plots related to EIS measurements of the cells using TREG-LiCF $3 \mathrm{SO}_{3}$ (Fig. S3a) and TREG-LiCF3 $\mathrm{SO}_{3}-\mathrm{LiNO}_{3}$ (Fig. S3b). Both panels reveal impedance responses characterized by a high-medium frequency semicircle due to the SEI over the electrode surface. ${ }^{69}$ In addition, the cell using TREG-LiCF $3 \mathrm{SO}_{3}-\mathrm{LiNO}_{3}$ exhibits a low frequency response attributed finite-length Warburg-type behavior ${ }^{70}$ after 4 days of storage, thus suggesting different features of the SEI owing to $\mathrm{LiNO}_{3}$. The impedance data have been analyzed by NLLS fit (see the experimental section for further details), in order to evaluate the lithium/electrolyte interface resistance; the related results are shown in Fig. 3c. The interface resistance of TREG$\mathrm{LiCF}_{3} \mathrm{SO}_{3}$ quickly grows to $260 \Omega$ during the first day upon SEI formation ${ }^{71}$ and slightly increases up to $280 \Omega$ throughout the following days. After 10 days of storage, the cell exhibits an interface resistance drop to about $200 \Omega$, attributed to partial dissolution/degradation of the passivation layer, ${ }^{72}$ and further interface stabilization. On the other hand, TREG-LiCF $3 \mathrm{SO}_{3}-\mathrm{LiNO}_{3}$ reveals stable lithium/electrolyte interface upon storage, after initial increase due to SEI formation, ${ }^{71}$ which is reflected into interface resistance values ranging between $110 \Omega$ and $160 \Omega$. 


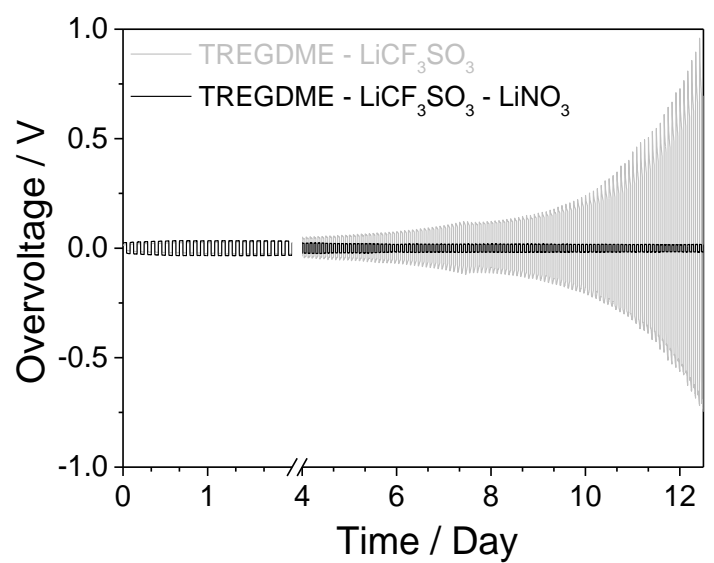

(a)

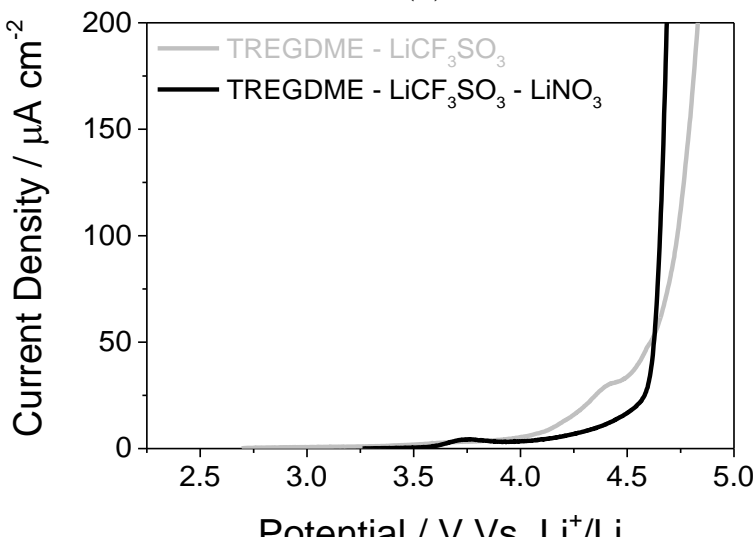

(b)

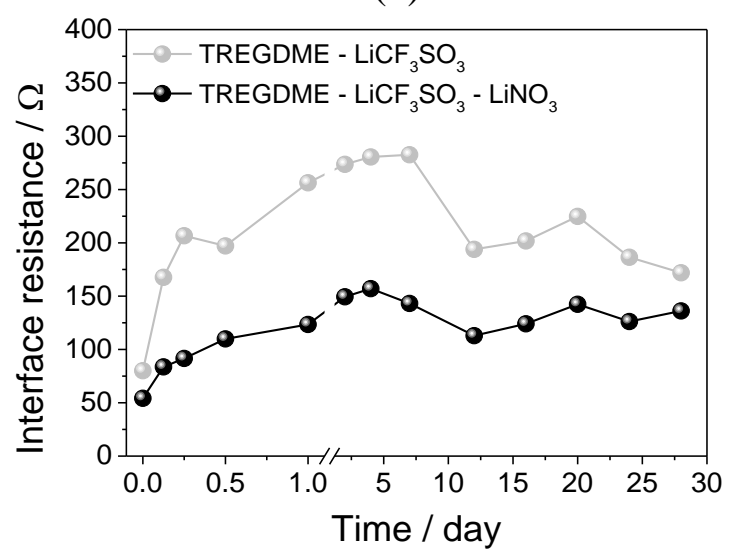

(c)

Figure 3. (a) Lithium stripping/deposition test of TREG-LiCF $3 \mathrm{SO}_{3}$ and TREG-LiCF $3 \mathrm{SO}_{3}-\mathrm{LiNO}_{3}$ (see the experimental section for sample acronyms) in symmetrical $\mathrm{Li} / \mathrm{Li}$ cell at constant current of 0.1 mA cm${ }^{-2}$; voltage limit: $+1 \mathrm{~V}$ and $-1 \mathrm{~V}$; step time: 1 hour each. (b) Anodic stability window of TREG-LiCF $3 \mathrm{SO}_{3}$ and TREG-LiCF $3 \mathrm{SO}_{3}-\mathrm{LiNO}_{3}$ (see the experimental section for sample acronyms) as determined by linear sweep voltammetry of three-electrode cells at $0.1 \mathrm{mV} \mathrm{s}^{-1}$ scan rate (carboncoated Al disk working electrode, $\mathrm{Li}$ metal counter and reference electrodes, respectively). (c) Interface resistance of TREG- $\mathrm{LiCF}_{3} \mathrm{SO}_{3}$ and $\mathrm{TREG}-\mathrm{LiCF}_{3} \mathrm{SO}_{3}-\mathrm{LiNO}_{3}$ (see the experimental section for sample acronyms) as calculated by NLLS ${ }^{63}$ of EIS tests on $\mathrm{Li} / \mathrm{Li}$ symmetrical cells throughout storage. 
In summary, $\mathrm{LiNO}_{3}$ addition to the glyme-based solution has beneficial effects on the lithium/electrolyte interface, since it promotes the formation of a stable SEI layer. This phenomenon has been widely investigated for Li-S batteries. ${ }^{37,38,55,56,73}$ Furthermore, we have recently reported an electrochemical activation technique consisting in potential decrease down to $1 \mathrm{~V} \mathrm{vs}$. $\mathrm{Li}^{+} / \mathrm{Li}$ to reduce $\mathrm{LiNO}_{3}$ at the working electrode. This procedure allowed the efficient use of a polyethylene glycol dimethyl ether PEGDME-LiCF $3 \mathrm{SO}_{3}$ solution added by $\mathrm{LiNO}_{3}$ as the electrolyte in lithium cell using insertion cathodes. ${ }^{58}$ This intriguing behavior is herein further investigated for TREGDME-based electrolyte by cyclic voltammetry of lithium cells using carbon (Fig. 4a) and LFP (Fig. 4b) working electrodes.

The voltammetry of Fig. 4a clearly reveals for the TREG-LiCF $3 \mathrm{SO}_{3}$ electrolyte (light gray line) a positive current flow of about $15 \mu \mathrm{A}$ within the $2-4.3 \mathrm{~V} \mathrm{vs}$. $\mathrm{Li}^{+} / \mathrm{Li}$ potential range after the first charge, both during oxidation and during reduction scans. This undesired current flow may be attributed to parasitic decomposition processes of the pristine electrolyte at the carbon electrode. Furthermore, a current drift is observed by lowering the potential to $1 \mathrm{~V}$ vs. $\mathrm{Li}^{+} / \mathrm{Li}$ during the first reduction, which is attributed to further electrolyte reductive decomposition at the working electrode ${ }^{65}$ as well as to possible lithium arrangement within carbon. Oxidative positive current is also observed by the subsequent cycles, performed by limiting the potential cutoff to $2 \mathrm{~V} \mathrm{vs.} \mathrm{Li}^{+} / \mathrm{Li}$ (inset of Fig. 4a). ${ }^{58}$ Instead, the voltammetry of TREG-LiCF $3 \mathrm{SO}_{3}-\mathrm{LiNO}_{3}$ shows a different trend owing to the $\mathrm{LiNO}_{3}$ addition. The test reveals the small oxidation peak at $3.72 \mathrm{~V} \mathrm{vs.} \mathrm{Li}^{+} / \mathrm{Li}$, already observed in Fig. 3b, during the first anodic scan, and a narrow peak at $1.5 \mathrm{~V} \mathrm{vs.} \mathrm{Li}^{+} / \mathrm{Li}$ during the first cathodic scan, ascribed to the electro-reduction of $\mathrm{LiNO}_{3}$ at the working electrode. ${ }^{55,56}$ During the second anodic scan the peak at $3.72 \mathrm{~V} \mathrm{vs.} \mathrm{Li}^{+} / \mathrm{Li}$ increases, and drops by subsequent cycles (inset of Fig. 4a). The peak at $3.72 \mathrm{~V}$ vs. $\mathrm{Li}^{+} / \mathrm{Li}$, missing in the cyclic voltammetry of the pristine TREG-LiCF $3 \mathrm{SO}_{3}$, may be associated to $\mathrm{LiNO}_{3}$ indeed. Furthermore, the absence of undesired positive current flow for cell using TREG- $\mathrm{LiCF}_{3} \mathrm{SO}_{3}-\mathrm{LiNO}_{3}$ indicates that $\mathrm{LiNO}_{3}$ addition actually mitigates the parasitic processes due to electrolyte oxidation, thus suggesting this solution as suitable electrolyte for 
application in lithium cell using LFP. This aspect is confirmed by Fig. 4b, reporting the cyclic voltammetry in $\mathrm{Li} / \mathrm{LFP}$ cell of bare (light gray) and $\mathrm{LiNO}_{3}$-added (black) electrolytes. The cell using TREG-LiCF $\mathrm{SO}_{3}$ shows noisy voltammetry profiles and shift toward positive currents due to electrolyte decomposition, as already observed for the cell using the carbon electrode (compare Fig. $4 \mathrm{a}$ and $\mathrm{b}$ ). Furthermore, the continuous electrolyte electro-oxidation at the LFP working electrode during cycles progressively leads to additional issues such as peak broadening, remarkable increase of the charge-discharge polarization, and final cell failure (inset of Fig. 4b).

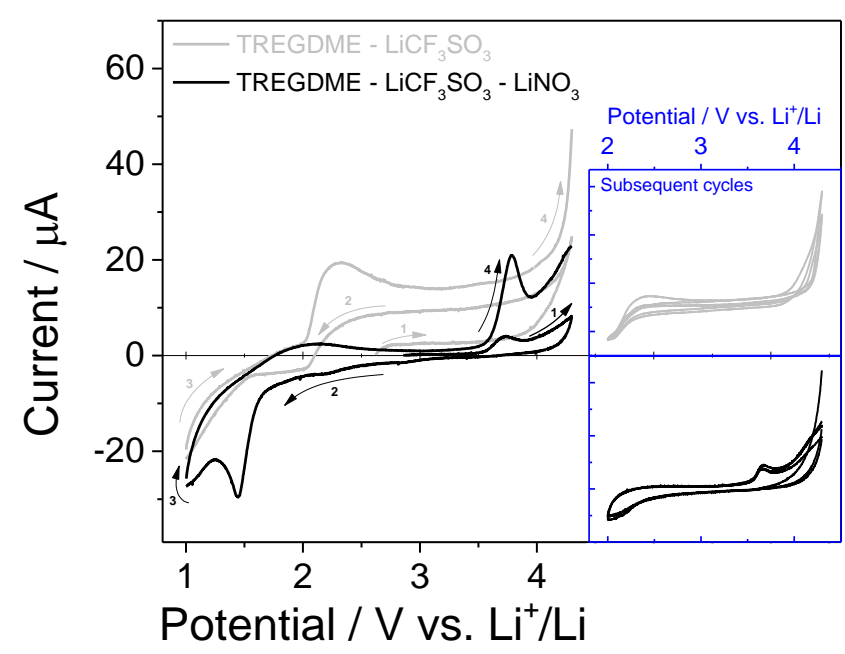

(a)

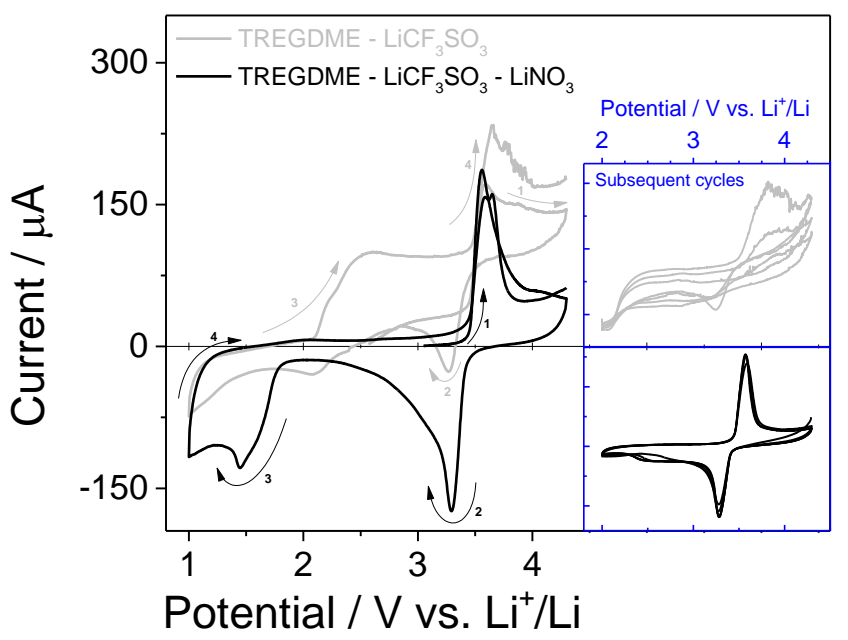

(b)

Figure 4. Cyclic voltammetry of TREG-LiCF $3 \mathrm{SO}_{3}$ (grey line) and TREG-LiCF $3 \mathrm{SO}_{3}-\mathrm{LiNO}_{3}$ (black line, see the experimental section for sample acronyms) used in three-electrode cells with Li metal as counter and reference electrodes; (a) carbon-coated Al disk working electrode and (b) LFP working electrode; scan rate: $0.1 \mathrm{mV} \mathrm{s}^{-1}$; potential range: $1-4.3 \mathrm{~V}$ vs. $\mathrm{Li}^{+} / \mathrm{Li}$ for the first cycle, $2-4.3 \mathrm{~V}$ vs. $\mathrm{Li}^{+} / \mathrm{Li}$ for the subsequent cycles; first cycles in the main figure; subsequent cycles in inset.

The voltammetry of the $\mathrm{Li} / \mathrm{TREG}-\mathrm{LiCF}_{3} \mathrm{SO}_{3}-\mathrm{LiNO}_{3} / \mathrm{LFP}$ cell shows a different trend characterized during the first cycle by narrow peaks centered at $3.45 \mathrm{~V}$ vs. $\mathrm{Li}^{+} / \mathrm{Li}$ due to the $\mathrm{Fe}^{3+} / \mathrm{Fe}^{2+}$ redox reaction within the olivine structure,${ }^{68}$ in addition to the previously discussed reduction peak at about $1.5 \mathrm{~V}$ vs. $\mathrm{Li}^{+} / \mathrm{Li}$ attributed to $\mathrm{LiNO}_{3}{ }^{55,56}$ The subsequent cycles overlap and the electrochemical 
process proceeds reversibly with limited polarization, following the typical profile associated with lithium (de-)insertion within $\mathrm{LiFePO}_{4}$ (inset of Fig. 4b).

Fig. 5 reports the Nyquist plots of the EIS tests performed throughout the voltammetry experiments. In particular, impedance spectra have been taken at open circuit voltage (OCV) and at the voltammetry cutoffs, i.e., at $4.3 \mathrm{~V}$ vs. $\mathrm{Li}^{+} / \mathrm{Li}$ at the end of charge as well as at $1 \mathrm{~V} \mathrm{vs.} \mathrm{Li}^{+} / \mathrm{Li}$ (first cycle) and at $2 \mathrm{~V}$ vs. $\mathrm{Li}^{+} / \mathrm{Li}$ (subsequent cycles) at the end of discharge. Fig. 5a reveals remarkable increase of the LFP/TREG- $\mathrm{LiCF}_{3} \mathrm{SO}_{3}$ interface resistance after three voltammetry cycles. On the other hand, Fig. $5 \mathrm{~b}$ reveals for the $\mathrm{LFP} / \mathrm{TREG}-\mathrm{LiCF}_{3} \mathrm{SO}_{3}-\mathrm{LiNO}_{3}$ interface a stable resistance after the first activation, which is reflected into the above discussed stability of the voltammetry profiles of Fig. 4b. This behavior suggests formation of a suitable LFP/electrolyte interface during the first voltammetry scan using the solution added by the $\mathrm{LiNO}_{3}$.

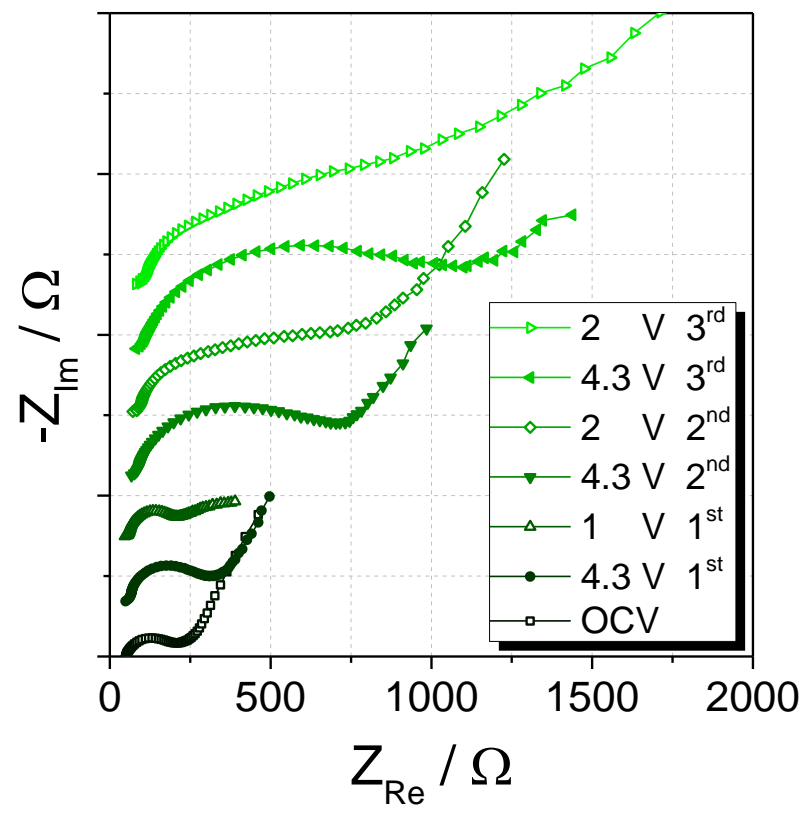

(a)

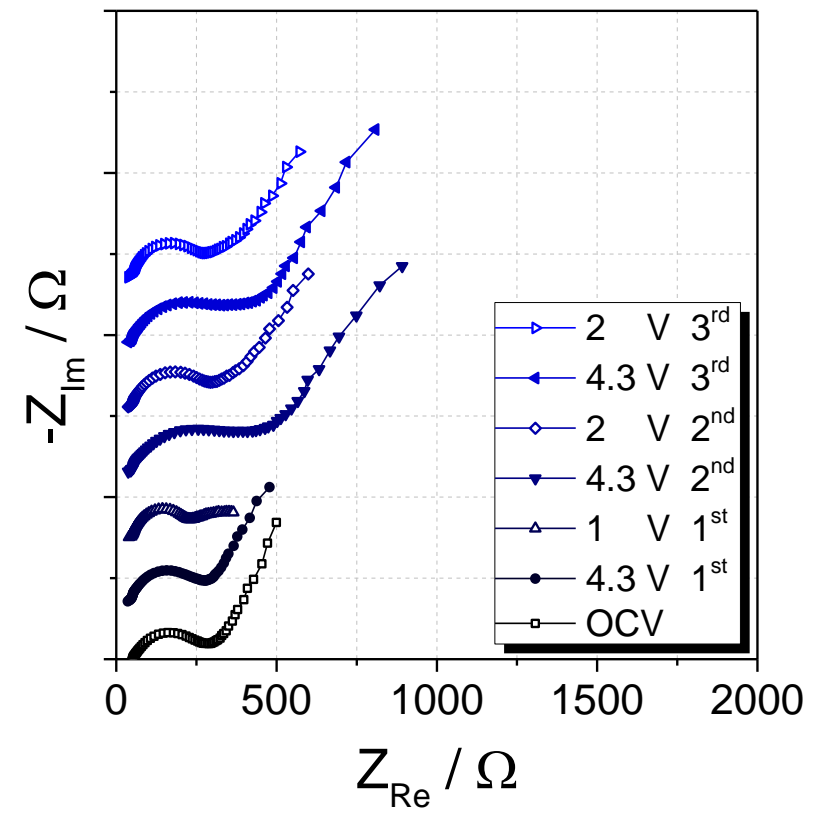

(b)

Figure 5. Nyquist plots related to EIS measurements carried out on three-electrode cells using LFP working electrode and lithium metal counter and reference electrodes; tests performed at the open circuit voltage (OCV) and at the end of each voltammetry cycle shown in Fig. 4. Cells using (a) TREG-LiCF $3 \mathrm{SO}_{3}$ and (b) TREG-LiCF $3 \mathrm{SO}_{3}-\mathrm{LiNO}_{3}$ (see the experimental section of the manuscript for sample acronyms). 
The electrochemical results of Figs. 3, 4 and 5 suggest $\mathrm{LiNO}_{3}$ as effective stabilizing agent for allowing proper operation of the lithium metal battery using LFP and TREGDME-based electrolyte. In particular, the lithium plating/stripping and cyclic voltammetry tests of Figs. 3a and 4 clearly reveal fast failure of the cells without $\mathrm{LiNO}_{3}$, which might be attributed to poor stability of the electrode/electrolyte at both anode and cathode sides. Accordingly, we reported in a previous work a comparison of the galvanostatic cycling behavior of two $\mathrm{Li} / \mathrm{LiFePO} 4$ cells using glyme-based electrolyte with and without $\mathrm{LiNO}_{3}{ }^{58}$ The paper revealed remarkable increase of cell polarization, electrolyte decomposition and high irreversible capacity upon cycling of the cell without $\mathrm{LiNO}_{3}$, which led to capacity fading from $150 \mathrm{mAh} \mathrm{g}^{-1}$ in the first cycle to a value as low as $0 \mathrm{mAh} \mathrm{g}^{-1}$ after only 37 cycles. Therefore, basing on the voltammetry tests reported herein as well as on our previous results we can confirm the stabilizing effects of $\mathrm{LiNO}_{3}$ addition to the electrolyte on the galvanostatic cycling trend of $\mathrm{Li} / \mathrm{TREG}-\mathrm{LiCF}_{3} \mathrm{SO}_{3}-\mathrm{LiNO}_{3} / \mathrm{LFP}$ cells (Fig. 6).

An electrochemical activation procedure of the cell for galvanostatic cycling, first proposed in our previous paper ${ }^{58}$ and herein further optimized, has been performed and shown in Fig. S4 of the Supporting Information (see the experimental section for further details). The figure indicates a plateau at about $1.7 \mathrm{~V}$ related to the $\mathrm{LiNO}_{3}$ reduction, according to the $\mathrm{CV}$ results shown in Fig. 4, and a $2^{\text {nd }}$ charge plateau with capacity exceeding the theoretical value for LFP $\left(170 \mathrm{mAh} \mathrm{g}^{-1}\right)$, partially attributed to electrolyte irreversible reaction occurring at about at $3.5 \mathrm{~V}$, which overlaps the $\mathrm{Fe}^{3+} / \mathrm{Fe}^{2+}$ redox reaction. It is noteworthy that the actual composition of the electrolyte solution reasonably changes due to the significant consumption of $\mathrm{LiNO}_{3}$ in the electrochemical activation process. However, the $1 \mathrm{~mol} \mathrm{~kg}^{-1}$ concentration of lithium nitrate ensures suitable cell operation after the activation process. Indeed, this process leads to formation of stable electrode/electrolyte interface, as confirmed by EIS in Fig. 5, as well as by galvanostatic tests of the Li/TREG-LiCF $3 \mathrm{SO}_{3}-\mathrm{LiNO}_{3} / \mathrm{LFP}$ cell performed at $\mathrm{C} / 5$ rate $\left(1 \mathrm{C}=170 \mathrm{~mA} \mathrm{~g}^{-1}\right)$ and reported in Fig. 6 in terms of voltage profile (a) and cycling trend (b). 
Fig. 6a reveals a flat voltage plateau centered at $3.45 \mathrm{~V}$, according to the two-phase reaction of $\mathrm{LiFePO}_{4},{ }^{68}$ with polarization as low as $0.05 \mathrm{~V}$. The cell stably delivers reversible capacity of about $125 \mathrm{mAh} \mathrm{g}^{-1}$, upon capacity increase during the first 10 cycles owing to structural stabilization of the olivine cathode and electrode wetting. ${ }^{60,65}$ However, the electrolyte formulation and the electrochemical activation procedure of the $\mathrm{Li} / \mathrm{TREG}-\mathrm{LiCF}_{3} \mathrm{SO}_{3}-\mathrm{LiNO}_{3} / \mathrm{LFP}$ cell herein proposed do not completely avoid a slight capacity fading after 70 cycles and a coulombic efficiency limited to 98\%. These issues, likely related to electrolyte side reaction, require additional work aimed at optimizing the electrolyte composition and improving the electrode/electrolyte stability, in order to further enhance the cell performances.

An additional $\mathrm{Li} / \mathrm{TREG}-\mathrm{LiCF}_{3} \mathrm{SO}_{3}-\mathrm{LiNO}_{3} / \mathrm{LFP}$ cell has been tested by galvanostatic cycling at several current rates, as shown by Fig. 6c, d. The voltage profiles of Fig. 6c reveal flat reversible plateaus with minor polarization increase due to current rise to $2 \mathrm{C}$ rate $\left(1 \mathrm{C}=170 \mathrm{mAh} \mathrm{g}^{-1}\right)$. The cell delivers reversible capacities of $133,129,125,120,112$ and $100 \mathrm{mAh} \mathrm{g}^{-1}$ at $\mathrm{C} / 10, \mathrm{C} / 5, \mathrm{C} / 3, \mathrm{C} / 2,1 \mathrm{C}$, and $2 \mathrm{C}\left(1 \mathrm{C}=170 \mathrm{~mA} \mathrm{~g}^{-1}\right)$, respectively. These performances clearly evidence the suitability of the electrolyte in lithium metal batteries by formation of a stable solid electrolyte interphase.

Beside the formation of stable SEI at the lithium surface by the addition of $\mathrm{LiNO}_{3}$, already demonstrated by several literature works, ${ }^{37,38,54,56}$ the electrochemical tests suggest the formation of a suitable layer over the LFP electrode during cell operation (see Fig. 4b discussion). 


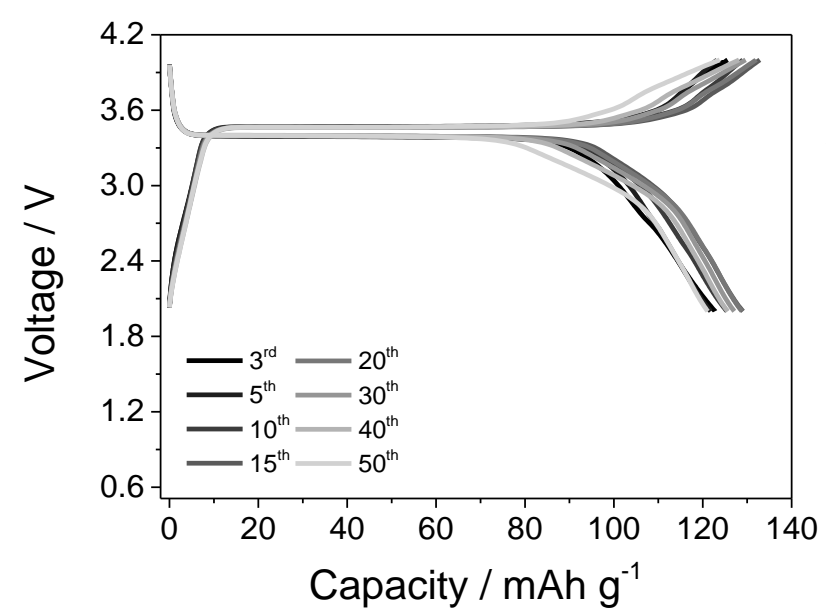

(a)

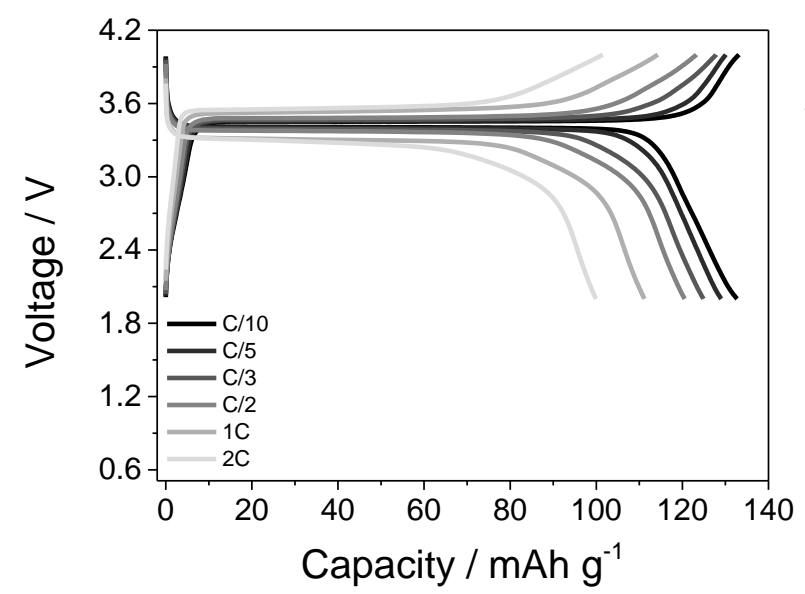

(c)

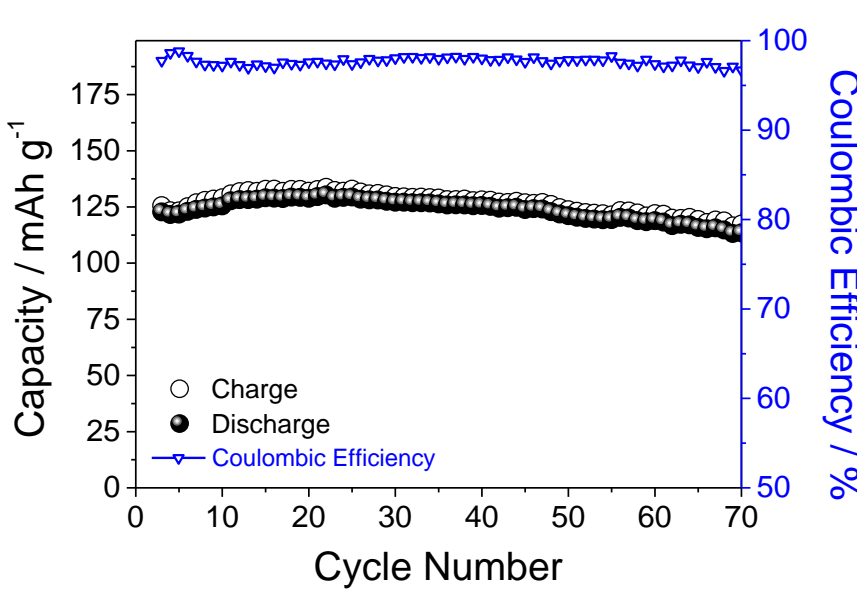

(b)

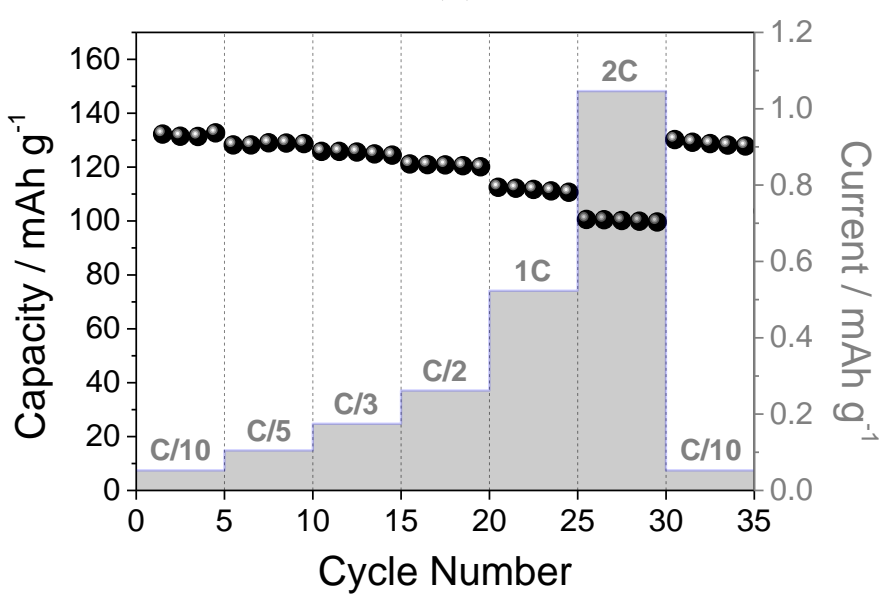

(d)

Figure 6. Galvanostatic cycling at $\mathrm{C} / 5$ rate $\left(1 \mathrm{C}=170 \mathrm{mAh} \mathrm{g}^{-1}\right)$ in terms of (a) voltage profile and (b) cycling behavior of a $\mathrm{Li} / \mathrm{TREG}-\mathrm{LiCF}_{3} \mathrm{SO}_{3}-\mathrm{LiNO}_{3} / \mathrm{LFP}$ cell (see the experimental section for sample acronyms) within $2-4 \mathrm{~V}$ voltage range (test performed after electrochemical activation as reported in Fig. S2 of the Supporting Information; see the experimental section for further details). Rate capability test at $\mathrm{C} / 10, \mathrm{C} / 5, \mathrm{C} / 3, \mathrm{C} / 2,1 \mathrm{C}, 2 \mathrm{C}$ rates $\left(1 \mathrm{C}=170 \mathrm{mAh} \mathrm{g}^{-1}\right)$ in terms of $(\mathbf{c})$ voltage profile and (d) cycling behavior of a $\mathrm{Li} / \mathrm{TREG}-\mathrm{LiCF}_{3} \mathrm{SO}_{3}-\mathrm{LiNO}_{3} / \mathrm{LFP}$ cell (see the experimental section for sample acronyms) within $2-4 \mathrm{~V}$ voltage range (test performed after electrochemical activation as reported in Fig. S2 of the Supporting Information; see the experimental section for further details).

This aspect is further investigated by ex situ SEM on LFP electrodes recovered from $\mathrm{Li} / \mathrm{TREG}-\mathrm{LiCF}_{3} \mathrm{SO}_{3}-\mathrm{LiNO}_{3} / \mathrm{LFP}$ cells. LFP electrodes have been recovered at the OCV (just after cell assembling and stabilization), after the first discharge, at the $10^{\text {th }}$ discharge, and the $50^{\text {th }}$ cycles of galvanostatic test (Fig. 7). The experiments clearly reveal a film growth during cell operation. It is worth noting that this film allows the $\mathrm{Li}^{+}$transport at the cathode and ensures stable 
cathode/electrolyte interface and reversible cycling, as shown by the EIS and galvanostatic tests of Figs. 5 and 6, respectively.

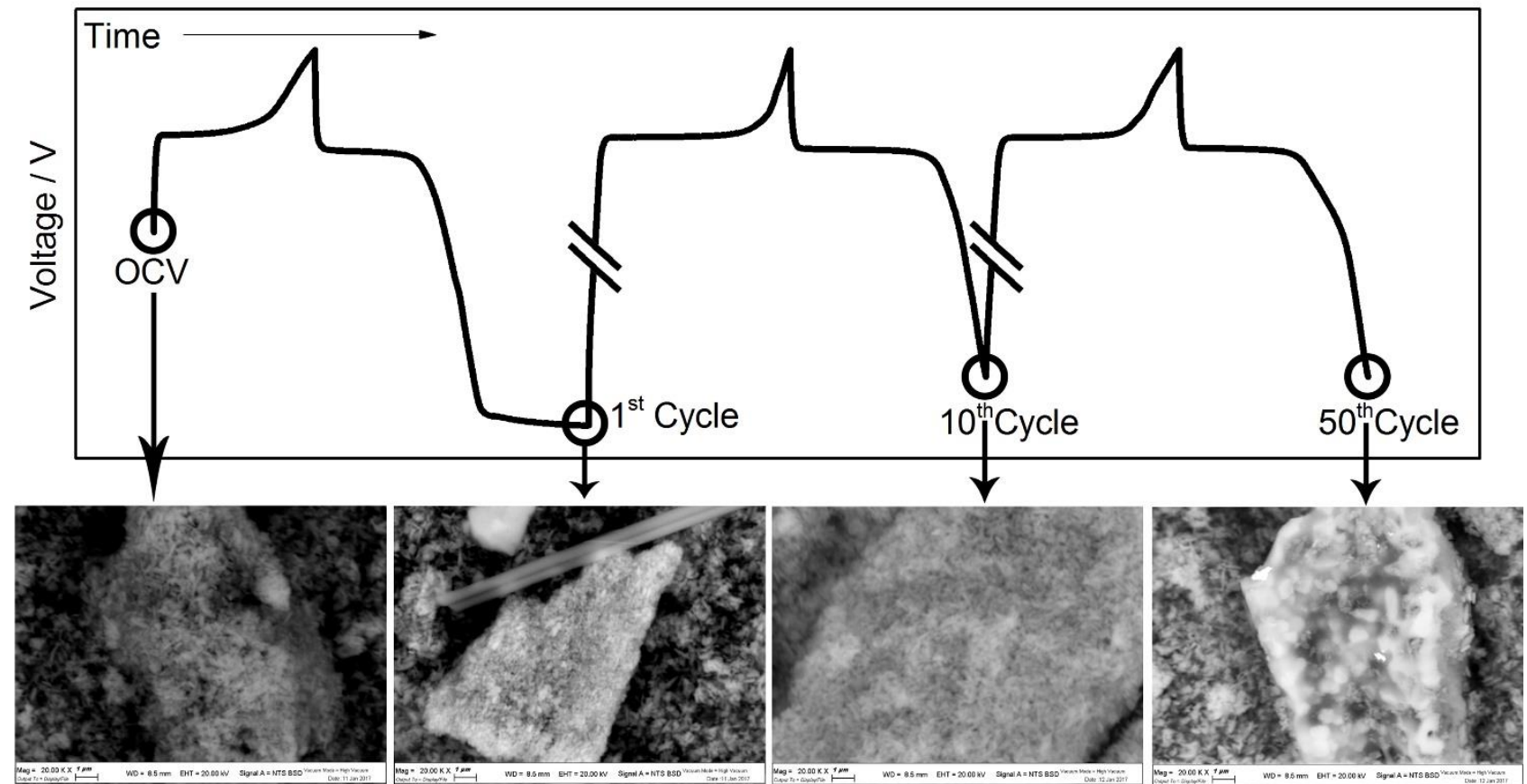

Figure 7. Ex situ $\mathrm{SEM}$ images of $\mathrm{LiFePO}_{4}$ electrodes recovered by $\mathrm{Li} / \mathrm{TREG}-\mathrm{LiCF}_{3} \mathrm{SO}_{3}-\mathrm{LiNO}_{3} / \mathrm{LFP}$ cells at the OCV (just after cell assembling and stabilization) and after the first, the $10^{\text {th }}$, and the $50^{\text {th }}$ galvanostatic cycles. First discharge performed by decreasing the voltage below $2 \mathrm{~V}$ at $\mathrm{C} / 5$ rate and limiting the time to $5.15 \mathrm{~h}$; subsequent cycles within the $2-4 \mathrm{~V}$ voltage range at $\mathrm{C} / 5$ rate $(1 \mathrm{C}=170$ $\left.\mathrm{mAhg}^{-1}\right)$

\section{Conclusion}

A new electrolyte solution formed by dissolving lithium triflate and lithium nitrate in triethylene glycol dimethyl ether was thoroughly investigated by PFG NMR, thermal, rheological, and electrochemical techniques. The results demonstrate very promising features suitable for lithium metal battery application and wide operating temperature range. The TREGDME- $\mathrm{LiCF}_{3} \mathrm{SO}_{3}$ solution has an ionic conductivity of $10^{-3} \mathrm{~S} \mathrm{~cm}^{-1}$, lithium transference number of about 0.5 , and association degree ranging from 0.85 to 0.95 with increasing temperature due to the formation of ion-ion couples. Furthermore, the $\mathrm{LiNO}_{3}$ addition to the electrolyte formulation played crucial role in determining the 
electrodes/electrolyte interfacial and electrochemical stability. Our study demonstrated that an electrochemical activation procedure promoting the $\mathrm{LiNO}_{3}$ reaction may allow full operation of the $\mathrm{Li} / \mathrm{TREGDME}-\mathrm{LiCF}_{3} \mathrm{SO}_{3}-\mathrm{LiNO}_{3} / \mathrm{LiFePO}_{4}$ cell. The battery revealed stable galvanostatic cycling, with polarization as low as $0.05 \mathrm{~V}$ cell, coulombic efficiency higher than $98 \%$ and reversible capacity ranging between $133 \mathrm{mAh} \mathrm{g}^{-1}$ at $\mathrm{C} / 10$ and $100 \mathrm{mAh} \mathrm{g}^{-1}$ at $2 \mathrm{C}$ rates at about $3.5 \mathrm{~V}$. Accordingly, the estimated theoretical energy density of the system is about $460 \mathrm{Wh} \mathrm{kg}^{-1}$. This value might lead to a practical energy density of the order of $150 \mathrm{Wh} \mathrm{kg}^{-1}$ in a lithium-ion battery using conventional carbon based anodes. However, the use of lithium metal anode, allowed by the low flammability of glyme-based electrolytes, ${ }^{59}$ may increase the energy density of the battery to an estimated value of the order of $200 \mathrm{Wh} \mathrm{kg}^{-1} \cdot{ }^{17}$

\section{Acknowledgements}

The work was performed within the collaboration project "Accordo di Collaborazione Quadro 2015" between University of Ferrara (Department of Chemical and Pharmaceutical Sciences) and Sapienza University of Rome (Department of Chemistry) and the project "Fondo di Ateneo per la Ricerca Locale FAR 2016", University of Ferrara. The work at Hunter College was supported by a grant from the U.S. Office of Naval Research and the NMR Facility is partially supported by a

National Institutes of Health RCMI infrastructure grant (MD007599). The authors thank the Helmholtz Institute Ulm, Karlsruhe Institute of Technology, for performing viscosity and thermogravimetric measurements.

\section{Supporting Information}

Ball-and-stick model of the electrolyte species; thermogravimetric, rheological and ionic conductivity study of the electrolyte materials; EIS during storage of $\mathrm{Li} / \mathrm{Li}$ symmetrical cells using TREGDME-LiCF $3 \mathrm{SO}_{3}$ and TREGDME-LiCF $3 \mathrm{SO}_{3}-\mathrm{LiNO}_{3}$ electrolytes; electrochemical activation of the $\mathrm{Li} / \mathrm{TREGDME}-\mathrm{LiCF}_{3} \mathrm{SO}_{3}-\mathrm{LiNO}_{3} / \mathrm{LFP}$ cell. 


\section{References}

(1) Scrosati, B. History of Lithium Batteries. J. Solid State Electrochem. 2011, 15, 1623-1630.

(2) Xu, W.; Wang, J.; Ding, F.; Chen, X.; Nasybulin, E.; Zhang, Y.; Zhang, J.-G. Lithium Metal Anodes for Rechargeable Batteries. Energy Environ. Sci. 2014, 7, 513-537.

(3) Balakrishnan, P. G.; Ramesh, R.; Prem Kumar, T. Safety Mechanisms in Lithium-Ion Batteries. J. Power Sources 2006, 155, 401-414.

(4) Wang, Q.; Ping, P.; Zhao, X.; Chu, G.; Sun, J.; Chen, C. Thermal Runaway Caused Fire and Explosion of Lithium Ion Battery. J. Power Sources 2012, 208, 210-224.

(5) Tarascon, J. M.; Armand, M. Issues and Challenges Facing Rechargeable Lithium Batteries. Nature 2001, 414, 359-367.

(6) Aurbach, D.; Levi, M. D.; Levi, E.; Schechter, A. Failure and Stabilization Mechanisms of Graphite Electrodes. J. Phys. Chem. B 1997, 101, 2195-2206.

(7) Aurbach, D. A Comparative Study of Synthetic Graphite and Li Electrodes in Electrolyte Solutions Based on Ethylene Carbonate-Dimethyl Carbonate Mixtures. J. Electrochem. Soc. 1996, $143,3809-3820$.

(8) Whittingham, M. S. History, Evolution and Future Status of Energy Storage. Proc. IEEE 2012, 100, 1518-1534.

(9) Chang, C.-H.; Chung, S.-H.; Manthiram, A. Effective Stabilization of a High-Loading Sulfur Cathode and a Lithium-Metal Anode in Li-S Batteries Utilizing SWCNT-Modulated Separators. Small 2016, 12, 174-179.

(10) Kim, J.; Lee, D. J.; Jung, H. G.; Sun, Y. K.; Hassoun, J.; Scrosati, B. An Advanced LithiumSulfur Battery. Adv. Funct. Mater. 2013, 23, 1076-1080.

(11) Jayaprakash, N.; Shen, J.; Moganty, S. S.; Corona, A.; Archer, L. A. Porous Hollow Carbon@sulfur Composites for High-Power Lithium-Sulfur Batteries. Angew. Chemie 2011, 50, 5904-5908.

(12) Suo, L.; Hu, Y.-S.; Li, H.; Armand, M.; Chen, L. A New Class of Solvent-in-Salt Electrolyte 
for High-Energy Rechargeable Metallic Lithium Batteries. Nat. Commun. 2013, 4, 1481.

(13) Peng, Z.; Freunberger, S. a.; Chen, Y.; Bruce, P. G. A Reversible and Higher-Rate Li-O2 Battery. Science. 2012, 337, 563-566.

(14) Elia, G. A.; Hassoun, J.; Kwak, W. J.; Sun, Y. K.; Scrosati, B.; Mueller, F.; Bresser, D.; Passerini, S.; Oberhumer, P.; Tsiouvaras, N.; Reiter, J. An Advanced Lithium-Air Battery Exploiting an Ionic Liquid-Based Electrolyte. Nano Lett. 2014, 14, 6572-6577.

(15) Liu, Q.-C.; Xu, J.-J.; Yuan, S.; Chang, Z.-W.; Xu, D.; Yin, Y.-B.; Li, L.; Zhong, H.-X.; Jiang, Y.-S.; Yan, J.-M.; Zhang, X.-B. Artificial Protection Film on Lithium Metal Anode toward Long-Cycle-Life Lithium-Oxygen Batteries. Adv. Mater. 2015, 27, 5241-5247.

(16) Elia, G. A.; Hassoun, J. A Polymer Lithium-Oxygen Battery. Sci. Rep. 2015, 5, 12307.

(17) Winter, M.; Besenhard, J. O.; Spahr, M. E.; Novák, P. Insertion Electrode Materials for Rechargeable Lithium Batteries. Adv. Mater. 1998, 10, 725-763.

(18) Cheng, X.-B.; Zhang, Q. Dendrite-Free Lithium Metal Anodes: Stable Solid Electrolyte Interphases for High-Efficiency Batteries. J. Mater. Chem. A 2015, 3, 7207-7209.

(19) Kozen, A. C.; Lin, C.-F.; Pearse, A. J.; Schroeder, M. A.; Han, X.; Hu, L.; Lee, S.-B.; Rubloff, G. W.; Noked, M. Next-Generation Lithium Metal Anode Engineering via Atomic Layer Deposition. ACS Nano 2015, 9, 5884-5892.

(20) Cao, Y.; Meng, X.; Elam, J. W. Atomic Layer Deposition of Li X Al Y S Solid-State Electrolytes for Stabilizing Lithium-Metal Anodes. ChemElectroChem 2016, 3, 858-863.

(21) Li, N.-W.; Yin, Y.-X.; Yang, C.-P.; Guo, Y.-G. An Artificial Solid Electrolyte Interphase Layer for Stable Lithium Metal Anodes. Adv. Mater. 2016, 28, 1853-1858.

(22) Croce, F.; Appetecchi, G. B.; Persi, L.; Scrosati, B. Nanocomposite Polymer Electrolytes for Lithium Batteries. Nature 1998, 394, 456-458.

(23) Hassoun, J.; Scrosati, B. Moving to a Solid-State Configuration: A Valid Approach to Making Lithium-Sulfur Batteries Viable for Practical Applications. Adv. Mater. 2010, 22, $5198-5201$. 
(24) Kimura, K.; Matsumoto, H.; Hassoun, J.; Panero, S.; Scrosati, B.; Tominaga, Y. A Quaternary Poly(ethylene Carbonate)-Lithium Bis(trifluoromethanesulfonyl)imide-Ionic Liquid-Silica Fiber Composite Polymer Electrolyte for Lithium Batteries. Electrochim. Acta 2015, 175, 134-140.

(25) Yamada, T.; Ito, S.; Omoda, R.; Watanabe, T.; Aihara, Y.; Agostini, M.; Ulissi, U.; Hassoun, J.; Scrosati, B. All Solid-State Lithium-Sulfur Battery Using a Glass-Type P2S5-Li2S Electrolyte: Benefits on Anode Kinetics. J. Electrochem. Soc. 2015, 162, A646-A651.

(26) Agostini, M.; Aihara, Y.; Yamada, T.; Scrosati, B.; Hassoun, J. A Lithium-sulfur Battery Using a Solid, Glass-Type P2S5-Li2S Electrolyte. Solid State Ionics 2013, 244, 48-51.

(27) Harding, J. R.; Amanchukwu, C. V.; Hammond, P. T.; Shao Horn, Y. Instability of Poly(ethylene Oxide) upon Oxidation in Lithium Air Batteries. J. Phys. Chem. C 2015, 119, $6947-6955$.

(28) Rajendran, S.; Mahalingam, T.; Kannan, R. Experimental Investigations on PAN - PEO Hybrid Polymer Electrolytes. Solid State Ionics 2000, 130, 143-148.

(29) Tobishima, S.; Morimoto, H.; Aoki, M.; Saito, Y.; Inose, T.; Fukumoto, T.; Kuryu, T. Glyme-Based Nonaqueous Electrolytes for Rechargeable Lithium Cells. Electrochim. Acta 2004, 49, 979-987.

(30) Devaux, D.; Bouchet, R.; Glè, D.; Denoyel, R. Mechanism of Ion Transport in PEO/LiTFSI Complexes: Effect of Temperature, Molecular Weight and End Groups. Solid State Ionics 2012, 227, 119-127.

(31) Carbone, L.; Gobet, M.; Peng, J.; Devany, M.; Scrosati, B.; Greenbaum, S.; Hassoun, J. Comparative Study of Ether-Based Electrolytes for Application in Lithium-Sulfur Battery. ACS Appl. Mater. Interfaces 2015, 7, 13859-13865.

(32) Aurbach, D.; Granot, E. The Study of Electrolyte Solutions Based on Solvents from the "glyme" Family (Linear Polyethers) for Secondary Li Battery Systems. Electrochim. Acta 1997, 42, 697-718. 
(33) Choquette, Y. Sulfamides and Glymes as Aprotic Solvents for Lithium Batteries. J. Electrochem. Soc. 1998, 145, 3500.

(34) Zhang, S.; Li, N.; Lu, H.; Zheng, J.; Zang, R.; Cao, J. Improving Lithium-Sulfur Battery Performance via a Carbon-Coating Layer Derived from the Hydrothermal Carbonization of Glucose. RSC Adv. 2015, 5, 50983-50988.

(35) Xiong, S.; Xie, K.; Diao, Y.; Hong, X. Characterization of the Solid Electrolyte Interphase on Lithium Anode for Preventing the Shuttle Mechanism in Lithium-Sulfur Batteries. J. Power Sources 2014, 246, 840-845.

(36) Barchasz, C.; Leprêtre, J.-C.; Alloin, F.; Patoux, S. New Insights into the Limiting Parameters of the Li/S Rechargeable Cell. J. Power Sources 2012, 199, 322-330.

(37) Xiong, S.; Xie, K.; Diao, Y.; Hong, X. Properties of Surface Film on Lithium Anode with LiNO 3 as Lithium Salt in Electrolyte Solution for Lithium-Sulfur Batteries. Electrochim. Acta 2012, 83, 78-86.

(38) Rosenman, A.; Elazari, R.; Salitra, G.; Markevich, E.; Aurbach, D.; Garsuch, A. The Effect of Interactions and Reduction Products of LiNO3, the Anti-Shuttle Agent, in Li-S Battery Systems. J. Electrochem. Soc. 2015, 162, A470-A473.

(39) Manthiram, A.; Fu, Y.; Chung, S.; Zu, C.; Su, Y. Rechargeable Lithium - Sulfur Batteries. Chemical Reviews. 2014, 114, 11751-11787.

(40) Manthiram, A.; Fu, Y.; Su, Y.-S. Challenges and Prospects of Lithium-Sulfur Batteries. Acc. Chem. Res. 2013, 46, 1125-1134.

(41) Yin, Y. X.; Xin, S.; Guo, Y. G.; Wan, L. J. Lithium-Sulfur Batteries: Electrochemistry, Materials, and Prospects. Angew. Chemie 2013, 52, 13186-13200.

(42) Zhang, S. S. Liquid Electrolyte Lithium/sulfur Battery: Fundamental Chemistry, Problems, and Solutions. J. Power Sources 2013, 231, 153-162.

(43) Moreno, N.; Agostini, M.; Caballero, A.; Morales, J.; Hassoun, J. A Long-Life Lithium Ion Sulfur Battery Exploiting High Performance Electrodes. Chem. Commun. 2015, 51, 14540- 
14542.

(44) Moreno, N.; Caballero, A.; Morales, J.; Agostini, M.; Hassoun, J. Lithium Battery Using Sulfur Infiltrated in Three-Dimensional Flower-like Hierarchical Porous Carbon Electrode. Mater. Chem. Phys. 2016, 180, 1-7.

(45) Agostini, M.; Xiong, S.; Matic, A.; Hassoun, J. Polysulfide-Containing Glyme-Based Electrolytes for Lithium Sulfur Battery. Chem. Mater. 2015, 27, 4604-4611.

(46) Grande, L.; Paillard, E.; Hassoun, J.; Park, J.-B.; Lee, Y.-J.; Sun, Y.-K.; Passerini, S.; Scrosati, B. The Lithium/Air Battery: Still an Emerging System or a Practical Reality? Adv. Mater. 2015, 27, 784-800.

(47) Elia, G. A.; Bernhard, R.; Hassoun, J. A Lithium-Ion Oxygen Battery Using a Polyethylene Glyme Electrolyte Mixed with an Ionic Liquid. RSC Adv. 2015, 5, 21360-21365.

(48) Laoire, C. O.; Mukerjee, S.; Plichta, E. J.; Hendrickson, M. A.; Abraham, K. M. Rechargeable Lithium/TEGDME-LiPF6/O2 Battery. J. Electrochem. Soc. 2011, 158, A302A308.

(49) Jung, H.-G.; Hassoun, J.; Park, J.-B.; Sun, Y.-K.; Scrosati, B. An Improved HighPerformance Lithium-Air Battery. Nat. Chem. 2012, 4, 579-585.

(50) Abraham, K. M. Electrolyte-Directed Reactions of the Oxygen Electrode in Lithium-Air Batteries. J. Electrochem. Soc. 2015, 162, A3021-A3031.

(51) Lee, D. J.; Hassoun, J.; Panero, S.; Sun, Y. K.; Scrosati, B. A Tetraethylene Glycol Dimethylether-Lithium Bis(oxalate)borate (TEGDME-LiBOB) Electrolyte for Advanced Lithium Ion Batteries. Electrochem. Commun. 2012, 14, 43-46.

(52) Bernhard, R.; Latini, A.; Panero, S.; Scrosati, B.; Hassoun, J. Poly(ethylenglycol)dimethylether-lithium Bis(trifluoromethanesulfonyl)imide, PEG500DME-LiTFSI, as High Viscosity Electrolyte for Lithium Ion Batteries. J. Power Sources 2013, 226, 329-333.

(53) Mikhaylik, Y. V.; Akridge, J. R. Polysulfide Shuttle Study in the Li/S Battery System. J. 
Electrochem. Soc. 2004, 151, A1969-A1976.

(54) Li, W.; Yao, H.; Yan, K.; Zheng, G.; Liang, Z.; Chiang, Y.-M.; Cui, Y. The Synergetic Effect of Lithium Polysulfide and Lithium Nitrate to Prevent Lithium Dendrite Growth. Nat. Commun. 2015, 6, 7436.

(55) Aurbach, D.; Pollak, E.; Elazari, R.; Salitra, G.; Kelley, C. S.; Affinito, J. On the Surface Chemical Aspects of Very High Energy Density, Rechargeable Li-Sulfur Batteries. $J$. Electrochem. Soc. 2009, 156, A694-A702.

(56) Zhang, S. S. Role of LiNO3 in Rechargeable Lithium/sulfur Battery. Electrochim. Acta 2012, $70,344-348$.

(57) Zhang, S. S. Effect of Discharge Cutoff Voltage on Reversibility of Lithium/Sulfur Batteries with $\mathrm{LiNO}_{3}$-Contained Electrolyte. J. Electrochem. Soc. 2012, 159, A920-A923.

(58) Carbone, L.; Gobet, M.; Peng, J.; Devany, M.; Scrosati, B.; Greenbaum, S.; Hassoun, J. Polyethylene Glycol Dimethyl Ether (PEGDME)-Based Electrolyte for Lithium Metal Battery. J. Power Sources 2015, 299, 460-464.

(59) Di Lecce, D.; Carbone, L.; Gancitano, V.; Hassoun, J. Rechargeable Lithium Battery Using Non-Flammable Electrolyte Based on Tetraethylene Glycol Dimethyl Ether and Olivine Cathodes. J. Power Sources 2016, 334, 146-153.

(60) Di Lecce, D.; Hassoun, J. Lithium Transport Properties in $\mathrm{LiMn}_{1-\alpha} \mathrm{Fe}_{\alpha} \mathrm{PO}_{4}$ Olivine Cathodes. J. Phys. Chem. C 2015, 119, 20855-20863.

(61) Stejskal, E. O.; Tanner, J. E. Spin Diffusion Measurements: Spin Echoes in the Presence of a Time-Dependant Field Gradient. J. Chem. Phys. 1965, 42, 288-292.

(62) Boukamp, B. A Package for Impedance/admittance Data Analysis. Solid State Ionics 1986, $18-19,136-140$.

(63) Boukamp, B. A. A Nonlinear Least Squares Fit Procedure for Analysis of Immittance Data of Electrochemical Systems. Solid State Ionics 1986, 20, 31-44.

(64) Lee, D.-J.; Park, J.-W.; Hasa, I.; Sun, Y.-K.; Scrosati, B.; Hassoun, J. Alternative Materials 
for Sodium Ion-sulphur Batteries. J. Mater. Chem. A 2013, 1, 5256-5261.

(65) Di Lecce, D.; Fasciani, C.; Scrosati, B.; Hassoun, J. A Gel-Polymer Sn-C/LiMn0.5Fe0.5PO4 Battery Using a Fluorine-Free Salt. ACS Appl. Mater. Interfaces 2015, 7, 21198-21207.

(66) Bogle, X.; Vazquez, R.; Greenbaum, S.; Cresce, A. V. W.; Xu, K. Understanding Li ${ }^{+}-$ Solvent Interaction in Nonaqueous Carbonate Electrolytes with ${ }^{17} \mathrm{O}$ NMR. J. Phys. Chem. Lett. 2013, 4, 1664-1668.

(67) Abbrent, S.; Greenbaum, S. Recent Progress in NMR Spectroscopy of Polymer Electrolytes for Lithium Batteries. Curr. Opin. Colloid Interface Sci. 2013, 18, 228-244.

(68) Padhi, A. K.; Nanjundaswamy, K. S.; Goodenough, J. B. Phospho-Olivines as PositiveElectrode Materials for Rechargeable Lithium Batteries. J. Electrochem. Soc. 1997, 144, $1188-1194$.

(69) Aurbach, D. Review of Selected Electrode-solution Interactions Which Determine the Performance of Li and Li Ion Batteries. J. Power Sources 2000, 89, 206-218.

(70) Franceschetti, D. R. Interpretation of Finite-Length-Warburg-Type Impedances in Supported and Unsupported Electrochemical Cells with Kinetically Reversible Electrodes. $J$. Electrochem. Soc. 1991, 138 (5), 1368-1371.

(71) Goodenough, J. B.; Kim, Y. Challenges for Rechargeable Li Batteries. Chem. Mater. 2010, $22,587-603$.

(72) Vetter, J.; Novàk, P.; Wagner, M. R.; Veit, C.; Muller, K. C.; Besenhard, J. O.; Winter, M.; Wohlfahrt-Mehrens, M.; Vogler, C.; Hammouche, A. Ageing Mechanisms in Lithium-Ion Batteries. J. Power Sources 2005, 147, 269-281.

(73) Barchasz, C.; Lepretre, J.-C.; Patoux, S.; Alloin, F. Revisiting TEGDME/DIOX Binary Electrolytes for Lithium/Sulfur Batteries: Importance of Solvation Ability and Additives. $J$. Electrochem. Soc. 2013, 160, A430-A436. 
Table of content entry

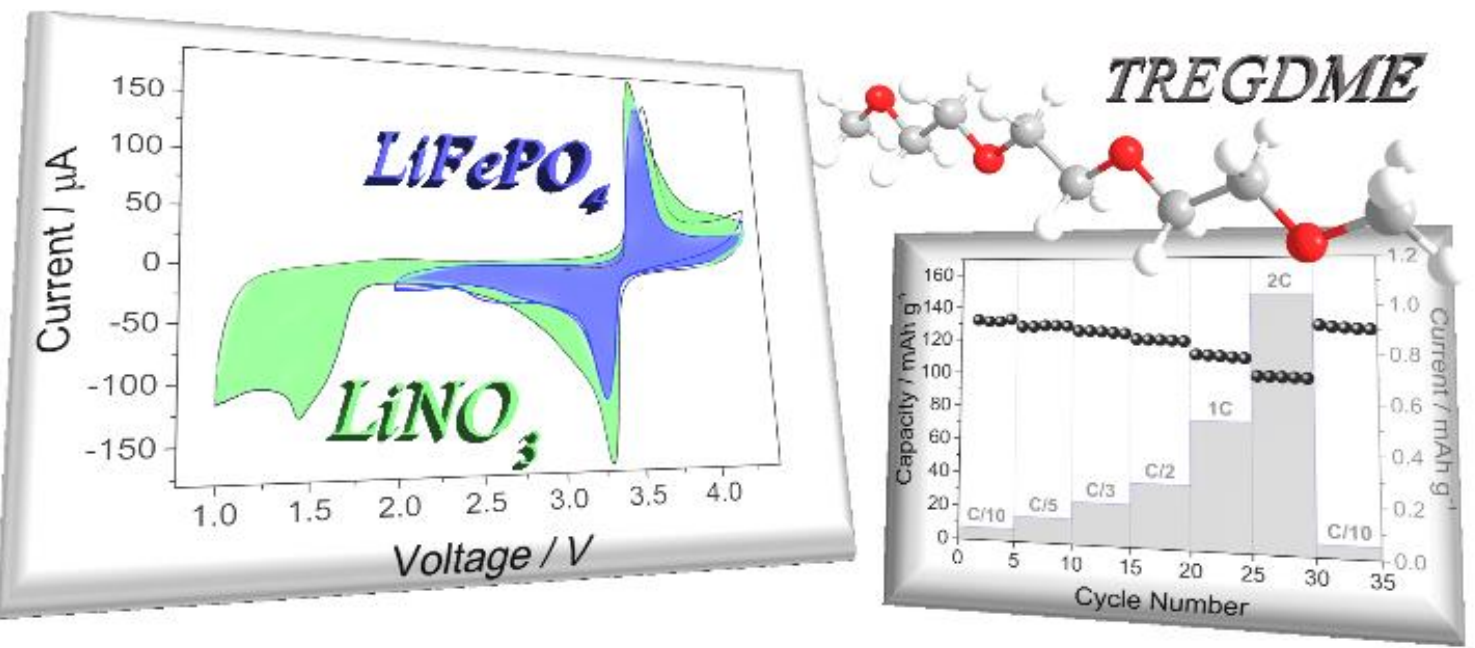

